Originally published at 96 Yale L.J. 743 (1987).

Copyright 1987 by Jack M. Balkin. All rights reserved.

\title{
DECONSTRUCTIVE PRACTICE AND LEGAL THEORY
}

\author{
J. M. Balkin ${ }^{p}$
}

The stone that the builders rejected has become the chief cornerstone.

—Psalms 118:22

*743 The purpose of this Article is to introduce legal readers to the ideas of the French philosopher Jacques Derrida, and to his philosophical practices regarding the interpretation of texts, sometimes known as deconstruction. ${ }^{1}$ The term 'deconstruction' is much used in legal writings these

p Assistant Professor of Law, University of Missouri-Kansas City. Harvard University A.B., 1978, J.D. 1981. I would like to thank my research assistants, Linda Talley, Suzanne Bardgett, and Jan Dodd, for their help in the preparation of this Article, and my colleagues, Joan Mahoney and James Kushner, for their comments on a previous draft.

${ }^{1}$ Derrida has developed his ideas in several books and essays dating from 1967, some of which have only recently been translated into English. J. DERRIDA, DISSEMINATION (B. Johnson trans. 1981) [hereinafter DISSEMINATION]; J. DERRIDA, MARGINS OF PHILOSOPHY (1982) [hereinafter MARGINS OF PHILOSOPHY]; J. DERRIDA, OF GRAMMATOLOGY (1976) [hereinafter OF GRAMMATOLOGY]; J. DERRIDA, POSITIONS (1981) [hereinafter POSITIONS]; J. DERRIDA, SPURS (1979) [hereinafter SPURS]; J. DERRIDA, SPEECH AND PHENOMENA (1973) [hereinafter SPEECH AND PHENOMENA]; J. DERRIDA, WRITING AND DIFFERENCE (1978) [hereinafter WRITING AND DIFFERENCE]; Derrida, The Law of Genre, 7 GLYPH 202 (1980); Derrida, Limited Inc abc . .., 2 GLYPH 162 (1977) [hereinafter Limited Inc abc].

The best general introduction to Derrida's thought is J. CULLER, ON DECONSTRUCTION (1982). Other good sources are H. STATEN, WITTGENSTEIN AND DERRIDA (1984) (suggesting Angelo-American philosophical approach to deconstruction); Johnson, Translator's Introduction to DISSEMINATION, supra, at vii; Rorty, Philosophy as a Kind of Writing: An 
days, ${ }^{2}$ and in this Article I propose to explain its philosophical underpinnings. Many persons who use the word 'deconstruction' regard it as no more than another expression for 'trashing,' that is, showing why legal $* \mathbf{7 4 4}$ doctrines are self-contradictory, ideologically biased, or indeterminate. ${ }^{3}$ By the term 'deconstruction,' however, I do not have in mind merely stinging criticism, but specific techniques and philosophical ideas that Derrida and his followers have applied to various texts. These techniques often do involve teasing out the hidden antinomies in our language and thought, and that is primarily how I came to be interested in them. ${ }^{4}$ However, I hope to demonstrate that 'deconstruction,' as I use the term, is not simply a fancy way of sticking out your tongue, but a practice that raises important philosophical issues for legal thinkers.

Lawyers should be interested in deconstructive techniques for at least three reasons. First, deconstruction provides a method for critiquing existing legal doctrines; in particular, a deconstructive reading can show how arguments offered to support a particular rule undermine themselves, and instead, support an opposite rule. Second, deconstructive techniques can show how doctrinal arguments are informed by and disguise ideological thinking. This can be of value not only to the lawyer who seeks to reform existing institutions, but also to

Essay on Derrida, 10 NEW LITERARY HIST. 141 (1978); Spivak, Translator's Preface to OF GRAMMATOLOGY, supra, at ix (essay requires familiarity with continental philosophers and Freud). None of these has considered the relevance of Derrida's thought to legal theory.

${ }^{2}$ See, e.g., Dalton, An Essay in the Deconstruction of Contract Doctrine, 94 YALE L.J. 997 (1985); Frug, The Ideology of Bureaucracy in American Law, 97 HARV. L. REV. 1276, 1288-99 (1984) (citing Derrida's notions of 'dangerous supplement'); Hegland, Goodbye to Deconstruction, 58 S. CAL. L. REV. 1203 (1985); Spann, Deconstructing the Legislative Veto, 68 MINN. L. REV. 473 (1984); Tushnet, Critical Legal Studies and Constitutional Law: An Essay in Deconstruction, 36 STAN. L. REV. 623 (1984); Note, Overshooting the Target: A Feminist Deconstruction of Legal Education,34 AM. U.L. REV. 1141 (1985); Hutchinson, From Cultural Construction to Historical Deconstruction (Book Review), 94 YALE L.J. 209, 229-35 (1984).

3 For example, Spann associates deconstruction with a critique of formalism in legal reasoning, or with the more general project of demonstrating that legal reasoning is indeterminate. Spann, supra note 2, at 536-43. But see Hegland, supra note 2, at 1203-05 (uses term 'deconstruction' in same way, but argues that premise of deconstruction is wrong; principles can be determined).

${ }^{4}$ I have argued that legal and moral thought in general is antinomal though not irrational. Balkin, The Crystalline Structure of Legal Thought, 39 RUTGERS L. REV. 1 (1987); Balkin, Taking Ideology Seriously: Ronald Dworkin and the CLS Critique, 55 U.M.K.C. L. REV. (forthcoming). 
the legal philosopher and the legal historian. Third, deconstructive techniques offer both a new kind of interpretive strategy and a critique of conventional interpretations of legal texts.

Although Derrida is a philosopher, his work has been applied mainly to problems of literary criticism; as a result much of the literature on deconstruction is written by literary critics and scholars. ${ }^{5}$ Adapting the work of Derrida and other literary critics to the problems of legal and political thought is not, however, as difficult as might first appear. Derrida is above all interested in the connection (and misconnection) between what we want to say and the signs we use to express our meaning. In short, he is interested in the interpretation of texts, and that is hardly strange territory for lawyers, who spend most of their time trying to understand what other lawyers have said in legal texts. On the other hand, explaining deconstructive practice is no small undertaking. Like many French intellectuals of his day, Derrida was schooled in the continental $* \mathbf{7 4 5}$ tradition of philosophy, whose major influences are Hegel, Husserl, and Heidegger. None of these philosophers is known for clarity of exposition, and Derrida often does little better than his intellectual predecessors. ${ }^{6}$ For this reason, I will attempt to translate his ideas into a form that can be more easily understood by those familiar with the Anglo-American schools of philosophy.

The use of the term 'translation' is quite deliberate. It is now commonplace to suggest that a translation can never fully capture the sense of the original. However, this point is especially significant in discussing Derrida's work. Derrida has chosen a self-consciously obscure and self- referential style, overflowing with concealed allusions and counterallusions. As I will discuss more fully later, his style may reflect his critique of Western thought's emphasis on

${ }^{5}$ E.g., H. BLOOM, P. DE MAN, J. DERRIDA, G. HARTMAN \& J. MILLER, DECONSTRUCTION AND CRITICISM (1979); J. CULLER, supra note 1; B. JOHNSON, THE CRITICAL DIFFERENCE (1980); V. LEITCH, DECONSTRUCTIVE CRITICISM (1983); P. DE MAN, ALLEGORIES OF READING: FIGURAL LANGUAGE IN ROUSSEAU, NIETZSCHE, RILKE, AND PROUST (1979); P. DE MAN, BLINDNESS AND INSIGHT (1983).

${ }^{6}$ At least one writer believes that structuralist and post- structuralist thinkers, most of whom were French, deliberately adopted an obfuscatory style in reaction to the bourgeois French preference for la clarite: a simple, clear, and elegant style in accordance with the 'narrower stylistic bounds of orthodox academic discourse' expected of French intellectuals. Sturrock, Introduction to STRUCTURALISM AND SINCE 16-17 (J. Sturrock ed. 1979). The style of modern French philosophical writers, such as Jacques Lacan, Roland Barthes, Michel Foucault, and Derrida, was designed to challenge that paradigm of 'proper' philosophical expression. Id. If this were in fact the goal of these writers, it bears noting that one can always have too much of a good thing. 
unambiguous and foundational concepts. ${ }^{7} \mathrm{I}$ am thus put in an especially precarious position because my goal is to represent clearly and simply the ideas of a philosopher who eschews clarity and simplicity in his own work. My explanation must involve a kind of alteration - I must simplify, interpret, and reinterpret Derrida as much as I explain him. ${ }^{8}$

I also engage in translation in the sense that Derrida does not write about legal, but rather about philosophical and literary, texts. In explaining Derrida's practices to a legal audience, I will focus on those areas of his work that have the most relevance to legal writing and thought. This too, requires selection, editorial judgment, and reinterpretation. What interests me most about Derrida's work is the possibility that deconstruction can shed light on theories of ideological thinking: how people form and use ideologies, consciously or unconsciously, in legal discourse. Derrida's work is not primarily about epistemology or the sociology of knowledge, but his work has relevance to these disciplines. For that reason, I emphasize some points in Derrida's writings that others (including Derrida) might not choose to emphasize.

A final obstacle to explaining deconstruction comes from the nature of Derrida's project. Because Derrida and his followers insist that deconstruction *746 is not a philosophical position but rather a practice, ${ }^{9}$ it is neither possible nor desirable to state a deconstructionist creed. Thus, my goal in this Article is to offer ways of bringing the concerns and methods of deconstructionists to the study of legal issues. Instead of describing what a deconstructionist believes, I will explain what a deconstructionist does and will attempt to show how one does 'it' to legal texts. Not surprisingly, underlying deconstructive activities are philosophical presuppositions about language, thought, and the world. Such

${ }^{7}$ See infra text accompanying notes $12-16$.

8 Indeed, a deconstructionist might argue that the process of repetition alters as it repeats, so that any explanation involves alteration of some sort. See infra note 53. This point takes on a special urgency with a writer as elusive as Derrida, whose very work celebrates the gap between that which represents and that which is represented.

${ }^{9}$ E.g., J. CULLER, supra note 1, at 95 (deconstruction as philosophical strategy); C. NORRIS, DECONSTRUCTION: THEORY AND PRACTICE 31 (1982) ( 'Deconstruction is . . . an activity of reading which remains closely tied to the texts it interrogates, and which can never set up independently as a self-enclosed system of operative concepts.'); C. NORRIS, THE DECONSTRUCTIVE TURN: ESSAYS IN THE RHETORIC OF PHILOSOPHY 6 (1983) ('It has become almost a ritual gesture among writers on deconstruction to insist that what they are doing is in no sense a species of conceptual exegesis or analysis. Deconstruction is first and last a textual activity.'). 
presuppositions are implicated in Derrida's work, even if he himself would not admit to them as a statement of a 'position.' I will try to make clear these hidden assumptions as the need arises. ${ }^{10}$

The two deconstructive practices that this Article will address are the inversion of hierarchies and the liberation of the text from the author. I believe these issues have the most relevance to what legal thinkers do when they analyze legal texts. They also have the most relevance to the study of ideology and the social and political theories underlying our legal system.

\section{THE INVERSION OF HIERARCHIES}

\section{A. The Metaphysics of Presence}

Described in its simplest form, the deconstructionist project involves the identification of hierarchical oppositions, followed by a temporary reversal of the hierarchy. Thus, to use Derrida's favorite example, if the history of Western civilization has been marked by a bias in favor of speech over writing we should investigate what it would be like if writing were more important than speech. We should attempt to see speech as a kind of writing, as ultimately parasitic upon writing, as a special case of writing, rather than the other way around. In so doing, we reverse the privileged position of speech over writing, and temporarily substitute a new priority. This new priority is not meant to be permanent, for it may in turn be reversed using identical techniques. The point is not to establish a new conceptual bedrock, but rather to investigate what happens when the $* 747$ given, 'common sense' arrangement is reversed. Derrida believes that we derive new insights when the privileging in a text is turned on its head.

For Derrida, hierarchies of thought are everywhere. They can be found in the following assertions: $\mathrm{A}$ is the rule and $\mathrm{B}$ is the exception; $\mathrm{A}$ is the general case and B is the special case; A is simple and B is complex; A is normal and B is abnormal; $\mathrm{A}$ is self-supporting and $\mathrm{B}$ is parasitic upon it; $\mathrm{A}$ is present and $\mathrm{B}$ is absent; A is immediately perceived and B is inferred; $\mathrm{A}$ is central and $\mathrm{B}$ is peripheral; A is true and B is false; A is natural and B is artificial. Indeed, my labelling of these ideas as A and B involves a hierarchical move because the letter A precedes $B$ in the alphabet.

For Derrida, any hierarchical statements about a set of ideas A and B is an invitation for a deconstructive reversal-to show that the property we ascribe to $\mathrm{A}$ is true of $\mathrm{B}$ and the property we ascribe to $\mathrm{B}$ is true of $\mathrm{A}$. Our deconstruction

${ }^{10}$ In doing so, my descriptions may well be seen by literary theorists, for example, as untrue to their understanding of deconstruction. However, just as deconstructive theorists take pride in the inability of others to systematize their work, I take comfort in the fact that an 'orthodox deconstruction' is a contradiction in terms. 
will show that A's privileged status is an illusion, for A depends upon B as much as B depends upon A. We will discover, then, that B stands in relation to A much like we thought A stood in relation to B. Indeed, it is possible to find in the very reasons that $\mathrm{A}$ is privileged over $\mathrm{B}$ the reasons that $\mathrm{B}$ is privileged over $\mathrm{A}$. Having reversed the hierarchy, we are able to see things about both A and B that we had never noticed before. ${ }^{11}$

Any hierarchical opposition of ideas, no matter how trivial, can be deconstructed in this way. For Derrida, however, deconstruction is more than a clever intellectual parlor game. It is a means of intellectual discovery, which operates by wrenching us from our accustomed modes of thought. In fact, Derrida was led to this practice of deconstruction by his dissatisfaction with Western philosophical practice from Plato's time to our own. ${ }^{12}$

Derrida sees his major project as exposing the bias in Western philosophy he calls the 'metaphysics of presence.'13 Each of the above oppositions privileges a kind of 'presence' over a corresponding kind of 'absence.' To Derrida, Western conceptions of philosophy proceed from the hidden premise that what is most apparent to our consciousness-what is $* \mathbf{7 4 8}$ most simple, basic, or immediate - is most real, true, foundational or important.

For example, the philosophical positions of an empiricist like Hume indicate a bias in favor of immediately perceived sense data. ${ }^{14}$ This is a privileging of 'presence' in Derrida's sense of the word. However, what Derrida

11 The word 'hierarchy' probably has political connotations to many legal readers. These connotations are unfortunate, for they may lead to a misunderstanding and oversimplification of Derrida's critique. Derrida's work is not concerned with the privileging of certain social groups over others (although it can be so applied), but with the privileging of certain ideas over others. We may, in fact, discover as we deconstruct legal texts that the privileging of ideas (as occurs in an ideology) has a connection to the privileged place that certain social groups enjoy. However, this connection is not a direct one. Our first task is to investigate the connections among ideas.

12 See J. CULLER, supra note 1 , at 92-94, 100; OF GRAMMATOLOGY, supra note 1 , at 3,10-18, 46; see also Rorty, supra note 1 , at 145 .

13 See OF GRAMMATOLOGY, supra note 1, at 49 (metaphysics of presence is irrepressible desire for transcendental signified presence, the thing itself, or truth); see also J. CULLER, supra note 1, at 92 ('Philosophy has been a 'metaphysics of presence,' the only metaphysics we know.').

${ }^{14}$ See generally D. HUME, A TREATISE OF HUMAN NATURE (L. Selby-Bigge $2 d$ ed. 1888) (all knowledge derived from sense data). 
means by 'presence' need not be the presence of sense data to the mind, for a philosopher like Plato would argue that it is a Form or Essence which the mind grasps most immediately ${ }^{15}$ and which is therefore most 'present.' Rather, Derrida sees the theories of Western philosophers as expressing, at various times, a series of different metaphysical valuations: subject over object, normal over abnormal, good over evil, positive over negative, identity over difference, being over non-being, ideal over non-ideal. Western philosophy has used the preferred concept as a ground for theorizing and has explained the other concept in terms of it. In each case, the preferred concept constitutes a belief in 'presence,' a self-sufficient, immediately cognizable existence. ${ }^{16}$

Three examples may help to demonstrate how Derrida hopes to reverse these oppositional hierarchies. I will begin with perhaps the most fundamental concept in Western thought - the notion of identity. Philosophers have regarded identity as a basic ground for metaphysical thought: Anything that exists is identical to itself. Difference is a derivative concept based upon identity: Two things are different if they are not identical. The deconstructionist wants to show that the notion of identity, which seems so basic, so 'present,' actually depends upon the notion of difference. Self-identity depends upon difference because a thing cannot be identical to something unless it can be different from something else. Identity is only comprehensible in terms of difference, just as difference can only be understood in terms of identity. We have just deconstructed the opposition identity/difference by showing the mutual dependence these ideas have upon each other. In doing so, we show that what was thought to be foundational (identity) is itself dependent upon the concept it was privileged over (difference).

It is true that having reversed this hierarchy, we could then show that difference cannot be a foundational term for metaphysics; difference depends upon identity as much as identity depends upon difference. This outcome is not a refutation of our previous deconstructive reading. The conclusion that neither term is foundational, but that both are mutually $* \mathbf{7 4 9}$ dependent upon each other, is precisely the conclusion that Derrida wants us to reach.

Next consider the opposition between serious discourse and non-serious discourse. ${ }^{17}$ This opposition also involves the metaphysics of presence, although at first glance the connection is not quite as obvious. When I am speaking seriously, I mean what I say to you, so that my true intentions are immediately

15 See PLATO, THE COLLECTED DIALOGUES OF PLATO 40, 575

(E. Hamilton \& H. Cairns eds. 1961) (theory of Forms in Phaedo and Republic).

${ }^{16}$ See WRITING AND DIFFERENCE, supra note 1, at 278-79; Limited Inc abc, supra note 1, at 236.

17 The discussion that follows is loosely based on Derrida's deconstruction of J.L. Austin's work in MARGINS OF PHILOSOPHY, supra note 1, at 307, 321-29, and in Limited Inc abc, supra note 1, at 162. 
present in the meaning of what I say. On the other hand, when I am not being serious, for example, when I am joking, lying, or reciting lines in a play, I do not really intend what I say. There is a divergence between my true thoughts and intentions and what you hear me saying. Now philosophers naturally are more concerned with serious discourse than non-serious, for serious discourse is, obviously, to be taken seriously. A philosopher would use the paradigm of serious communication as the foundation either for a theory of meaning or for a theory of performative speech acts like promising, warning, or marrying. Non-serious discourse, such as jokes, lies, or dramatic readings, is an aberration, an additional feature of discourse that one would explain in terms of serious discourse after one has worked out the basic theory of serious communication.

The opposition between the serious and the non-serious can be deconstructed in the same manner as the opposition between identity and difference. Once again, the goal is to subvert the notion that serious discourse is a self-contained, self-supporting ground upon which we can base a philosophical theory of meaning or promising.

To deconstruct this opposition, we must introduce the notion of iterability. Iterability is a property of signs. If one makes a sign, one can make the sign again at another time, in another place, in another context. In a simple sense, words are like signs. We are able to communicate because we can use words and combinations of words over and over again. If we had to create new signs to express our thoughts every time we attempted to communicate, we would never be able to communicate with anyone. Thus, iterability, or the property of being able to be repeated in many different contexts, is essential to any form of communication.

When I say 'It is raining outside' or 'I promise to pay you thirty dollars for that coat,' the statements I make are iterable. They can be repeated many different times, in many different places, and in many different contexts. I can say them when in fact I believe it is raining, or when I do intend to make a promise. But the feature of iterability means that I can also say them when I am merely joking or reciting lines in a $* \mathbf{7 5 0}$ play. Indeed, we are brought to the surprising conclusion that we could not use words to express ourselves seriously unless we could use the same words non-seriously. The same property of words that allows us to express what we mean requires that we also be able to express what we do not mean.

Serious discourse thus depends on the ability to make statements whether or not they conform with our true intentions. That is to say, the serious ultimately depends upon the prior existence of the non-serious. Indeed, we can go further. If we now reconceptualize 'non-serious' statements as those statements in which there is no necessary connection between the statement and real intention, we may describe serious statements as merely a special case of iterable 
non-serious statements in which what we say happens to coincide with what we really intend. ${ }^{18}$

The work of the Swiss linguist Ferdinand de Saussure presents a third example of deconstruction. Saussure distinguished between langue, the background system of linguistic rules, and parole, the set of speech acts made by members of a linguistic community. ${ }^{19}$ Saussure argued that langue was the more important element in the understanding of language because the system of relations among various signs is what constitutes a language. Specific examples of parole, that is specific speech acts by speakers in a linguistic community, are only possible because of the preexisting langue that speakers unconsciously rely upon to understand each other. Thus, the word 'cat' is possible in English because English speakers can distinguish it from 'mat,' 'cot,' and 'cad.' In this sense, languages are systems of differences; when an English speaker uses English words, those words carry with them the system of differences that makes them intelligible to other English speakers. In Derrida's terminology, English words carry the 'traces' of other words from which they are distinguished and in opposition to which they possess intelligibility. ${ }^{20}$

However, Saussure's privileging of langue over parole as the basis of language leads to an historical paradox: How did language begin at a time in which there was no established system of differences that constituted a language? As Jonathan Culler explains, 'If a cave man is successfully to inaugurate language by making a special grunt signifying 'food,' $* \mathbf{7 5 1}$ we must suppose that the grunt is already distinguished from other grunts and that the world has already been divided into the categories 'food' and 'non-food." 21

Language must have begun with speech acts, and through history the collection of past speech acts (parole) was consolidated to create a linguistic

18 In this last statement, I have used the word 'non-serious' in a new sense. Originally, I used it to mean 'not serious.' By the end of the deconstruction, however, it has taken on a new meaning, namely, 'stated without regard to whether the statement conforms to real intention.' In reversing the serious/non-serious opposition, I have created a broader notion of non-serious speech upon which both the serious and the non-serious (in the former sense of the word) depend. This is a common practice in a deconstructive reversal and involves the creation of a paleonym, a new concept with an old name that recalls the previously subordinated concept. See infra text accompanying notes $42-44$.

19 F. DE SAUSSURE, COURSE IN GENERAL LINGUISTICS 9, 13-15, 17-20, 77 (3d ed. 1959).

${ }^{20}$ See infra note 25 and accompanying text.

${ }^{21}$ See J. CULLER, supra note 1 , at 96. 
system (langue). On the other hand, speech acts could not have been understood without some pre-existing structure that made others understand that certain primordial grunts signified 'This is a rock,' rather than 'I am in pain.' No matter how far back we go in history, each speech act seems to require a pre- existing linguistic and semantic structure in order to be intelligible, but any such structure could not come into being without a history of pre-existing speech acts by past speakers. Neither langue nor parole could be a foundational concept in a theory of language because each is mutually dependent upon the existence of the other. ${ }^{22}$

\section{B. Differance and Trace}

The three examples of privileging that I have given all have a single feature in common. Once the hierarchy of the more basic term over the less basic term is deconstructed, we see that the more basic term depends upon the less basic. Because we already know that the less basic term depends upon the more basic, we end up asking the proverbial question: 'Which came first, the chicken or the egg?' This question neatly summarizes what Derrida is trying to show in deconstructing hierarchical oppositions. He is not attempting to show that we were wrong in thinking that difference is dependent upon identity, that the non-serious is dependent upon the serious, or that parole is dependent upon langue. Rather, he wants to expose what we have forgotten: that identity is also dependent upon difference, the serious is also dependent upon the non- serious, and langue is also dependent upon parole. In other words, neither term of the opposition can be originary and fundamental because both are related to each other in a system of mutual dependences and differences. Each is continually calling upon the other for its foundation, even as it is constantly defferentiating itself from the other.

*752 Derrida has a special term for the chicken-and-egg quality of mutual dependence and difference that the terms of hierarchical oppositions have for each other: differance. Differance is a pun based upon the French word differer, which means both to differ and to defer. Derrida replaces an 'e' with 'a' in difference to make it differance; the two words sound exactly the same in

22 See J. DERRIDA, Semiology and Grammatology, in POSITIONS, supra note 1, at 15, 17, 28 [hereinafter Semiology and Grammatology]. Culler refers to this as the paradox of structure and event. J. CULLER, supra note 1, at 94- 96. The same problem arises for theorists who explain obligations in terms of the existence of 'practices.' See Rawls, Two Concepts of Rules, 64 PHIL. REV. 3 (1955). Promissory obligations, for example, are explained by the practice of promising. See H.L.A. HART, THE CONCEPT OF LAW 42-43 (1961). By arguing that acts of promising could not come into being before the creation of a practice of promising, these thinkers face the problem of showing how a practice of promising could have arisen before there were any specific acts of promising. 
French. ${ }^{23}$ Differance simultaneously indicates that (1) the terms of an oppositional hierarchy are differentiated from each other (which is what determines them); (2) each term in the hierarchy defers the other (in the sense of making the other term wait for the first term), and (3) each term in the hierarchy defers to the other (in the sense of being fundamentally dependent upon the other).

From differance, we can understand the idea of 'trace.' Both of the terms in a hierarchical opposition rely for their coherence on the differentiation between them. The relation between identity and difference, serious and non-serious, langue and parole, is one of mutual dependence and difference, or differance. However, Derrida would also say that in each case the first concept bears the traces of the second concept, just as the second concept bears the traces of the first.

The word 'trace' is a metaphor for the effect of the opposite concept, which is no longer present but has left its mark on the concept we are now considering. ${ }^{24}$ The trace is what makes deconstruction possible; by identifying the traces of the concepts in each other, we identify their mutual conceptual dependence. ${ }^{25}$

One might ask whether the ideas of differance and trace between two opposed concepts could form a new ground for explaining both. However, differance and trace are not stable conceptions; they simply represent the play of differences and dependences between two mutually opposed concepts. Neither differance nor trace could serve as a foundational concept. ${ }^{26}$

${ }^{23}$ See MARGINS OF PHILOSOPHY, supra note 1, at 3; J. DERRIDA, Positions, in POSITIONS, supra note 1, at 39-40 [hereinafter Positions]; Semilogy and Grammatology, supra note 22, at 26-28.

${ }^{24}$ See OF GRAMMATOLOGY, supra note 1, at 46-47.

${ }^{25}$ See id. at 62-63. The phoneme /b/ is a sound in English because of its differentiation from the set of other available sounds in that language. The idea of 'trace' may be compared to the way in which speakers are able to distinguish /b/ from other phonemes, while simultaneously being able to identify the /b/ spoken by one person with the /b/ spoken by another. In a similar way, the concepts in hierarchical oppositions create the possibility for each other's existence; they form, shape, or identify each other by their absence. This necessary conceptual support is the 'trace' of the absent concept.

${ }^{26}$ See Positions, supra note 23, at 39-40. Note that this statement is itself deconstructible. The concept of differance is essential (hence foundational?) to Derrida's own thought, at least as I present it here.

Two points follow from this deconstruction. First, if we attempted to give concepts like 'differance' and 'trace' a special statutes, whether as foundations 
*753 Having seen one originary concept after another fall under the deconstructionist sword, the reader might be tempted to ask whether Derrida means to deny that there is any self-sufficient, originary foundation for a system of thought. This is precisely the point of the deconstructionist critique of Western philosophy. Proposed foundational terms all depend ultimately upon the subordinate concepts we would like to depend upon those foundational terms. Derrida is denying the validity of the Cartesian project of discovering an unquestionable, self-sufficient ground for philosophy. ${ }^{27}$

The notions of differance and trace suggest a revolutionary theory of how people grasp abstract ideas. Our commonsense view is that one holds an idea in one's mind, and that idea is immediately present as one conceives it. Thus,

for deconstruction or as ineffable concepts that escape analysis, we would fall into the very trap that Derrida seeks to avoid. Rorty, supra note 1, at 151-53. Thus, trace cannot be 'divinized,' as Rorty says, id. at 153, and neither can difference. These conceptions must simply describe the situation of foundationlessness, provisionality, or reversibility. The second point is that this lack of foundational concepts puts any expositor of Derrida's thought in an unfourtunate situation. These concepts are important to understanding Derrida, and one cannot do justice to his work without discussing them. I therefore present them as essential, although Derrida would not approve. This dilemma merely demonstrates the imposibility of giving a fully deconstructionist account of deconstruction. See infra note 54 .

${ }^{27}$ See Rorty, supra note 1, at 159. I use the term 'Cartesian' because in many ways Descartes is the high priest of the metaphysics of presence: Descartes believed that one could ultimately base a philosophical system upon the indubitable truth that one's existence is immediately present to one's own consciousness. R. DESCARTES, Meditations on First Philosophy, in THE PHILOSOPHICAL WORKS OF DESCARTES 131 (E. Haldane \& G. Ross trans. 1911).

The cogito of Descartes attempted to ground philosophy on a metaphysics of presence. Derrida did not need to deconstruct the assertion because David Hume had already performed the task. Hume argued that one's sense of identity is dependent upon the continuous flow of thoughts that one experiences. Thus, instead of thought being dependent upon the self's identity, identity is dependent upon the experience of thought. When Descartes said, 'I think, therefore I am,' he believed that he had demonstrated the privileged nature of existence over thought (I must be, in order to be thinking at all). Instead, Hume showed that Descartes' conclusion made knowledge of identity only an inference from the continuous experience of thought (I know that I exist because there is a continuous stream of thoughts). D. HUME, supra note 14, at 6 . A deconstructive reading of Descartes' cogito, then, demonstrates that identity and thought are mutually dependent upon each other in a relation of differance. 
when I think about the idea of identity, I am thinking about it, and not about another idea (difference). When I think about speech, I am thinking about speech and not about writing. But we can read Derrida's work as challenging this commonsense conception. When we hold an idea in our minds, we hold both the idea and its opposite; we think not of speech but of 'speech as opposed to writing,' or speech with the traces of the idea of writing, from which speech differs and upon which it depends. ${ }^{28}$ The history of ideas, then, is not the history of individual conceptions, but of favored conceptions held in opposition to disfavored conceptions. ${ }^{29}$

*754 It might seem at first that deconstructive practice is less important to lawyers than to philosophers. Derrida's critique of foundational thinking might be of great concern to philosophers searching for ultimate truth. Philosophy usually involves a search for ultimate groundings, and so the power of Derrida's critique is troubling. On the other hand, we do not expect that all or even most legal doctrines can be proven to have a basis in objective moral truth. Law is a much more pragmatic enterprise than philosophy. However, Derrida's critique is not simply directed at metaphysics. Derrida's point is that the privileging of presence may be found in everyday thought as much as in abstract philosophy. Any system of thought that proceeds by marking out the fundamental, the essential, the normal, or the most important-in short, virtually any rational system—can be analyzed from the standpoint of deconstructive practice.

Our understanding of legal ideas may indeed involve, as Derrida says of speech and writing, the simultaneous privileging of ideas over their opposites. Legal doctrines are based upon a group of foundational concepts and principles. Thus, in tort law, one learns the basic concepts of fault, intent, or causation, and more recently, the notions of cost-benefit analysis and economic efficiency. Such concepts are building blocks for further development. Using Derrida's methods, we discover that each legal concept is actually a privileging, in disguise, of one

${ }^{28}$ See Semiology and Grammatology, supra note 22, at 26. What speech is opposed to, of course, depends upon the context.

29 This is an epistemological interpretation of Derrida. Derrida does not purport to offer a theory specifically about epistemology, metaphysics, or any traditional field of philosophy. Indeed, Derrida would probably resist the idea that his theories were 'about' anything in particular, although it is my belief that they have many applications in such fields as literary criticism, philosophy, psychology, and law. I offer my interpretation because of the connection I am about to make between privileging and ideological thinking. If we apply Derrida's work to the way people formulate and use legal concepts, we are making a point about human psychology and the sociology of knowledge. An epistemological interpretation is consistent with the work of Derrida's structuralist predecessors, such as Saussure and Levi-Strauss. These thinkers argue that human consciousness is structured in terms of mutually defined oppositions. See generally T. HAWKES, STRUCTURALISM AND SEMIOTICS 19-58 (1977). 
concept over another. By revealing the opposition, and deconstructing it, we are brought to an entirely different vision of moral and legal obligation.

One example of legal doctrines' reliance on privileging is the Supreme Court's doctrine of standing. By holding that the Constitution requires a plaintiff to show 'actual' injury in order to sue, ${ }^{30}$ the Court has created a privileging of plaintiffs who have actual injury over plaintiffs whom the Court classifies as purely 'ideological. ${ }^{31}$ One way to deconstruct this opposition would be to show how arguments in favor of the actual injury requirement 'undo' themselves. The goal would be to examine the standard arguments for the actual injury requirement: Plaintiffs with actual injury are more reliable, more adversarial, and more likely to present a concrete record for decision. We could then use these arguments against themselves to demonstrate that ideological plaintiffs also possess these desired $* \mathbf{7 5 5}$ traits. Conversely, we could show how plaintiffs who possess actual injury, but who lack ideological zeal, are less dependable, less adversarial, and less likely to produce a concrete record for decisionmaking than their ideological counterparts. ${ }^{32}$

This example suggests that law provides a fertile field of discourse for deconstructive readings. Lawyers are continually involved in establishing principles of regulatory behavior, whether in contract law, constitutional law, or other areas, and this project necessitates the privileging of concepts. Deconstruction can serve another purpose. The law reflects social visions that involve privilegings of particular conceptions of human nature. As we deconstruct legal principles, we deconstruct the ideology or world view that informs them. Although we can use deconstruction to show that doctrines are incomplete, or that the arguments for a given doctrine 'undo' themselves, we can also use deconstruction as a tool for ideological and historical analysis.

\section{Arguments that Undo Themselves}

Deconstructive reversals show that the reasons given for privileging one side of an opposition over the other often turn out to be reasons for privileging the other side. The virtues of the first term are seen to be the virtues of the second; the vices of the second are revealed to be true of the first as well. This undoing of justifications for privileging is part of the deconstructionist aim of 'ungrounding'

30 See, e.g., Warth v. Seldin, 422 U.S. 490 (1975).

31 See, e.g., Schlesinger v. Reservists Comm. to Stop the War, 418 U.S. 208 (1974); Sierra Club v. Morton, 405 U.S. 727 (1972).

32 For examples of deconstruction of this doctrine, see Tushnet, The Sociology of Article III: A Response to Professor Brilmayer, 93 HARV. L. REV. 1698 (1980); J. Balkin, Deconstructing Article III (Sept. 27, 1986) (unpublished manuscript on file at Yale Law School Library). 
preferred conceptions by showing that they cannot act as self-sufficient or self-explanatory grounds or foundations.

The most famous example of this 'ungrounding' is Derrida's treatment of speech and writing in Of Grammatology. ${ }^{33}$ Derrida finds in the texts of several writers, including Rousseau, Saussure, and Levi-Strauss, a consistent valuing of speech over writing as a form of communication. ${ }^{34}$ Derrida argues that this preference is not accidental; it relates to the general 'logocentric' bias of Western thought. ${ }^{35}$ By 'logocentric,' Derrida means centered on the concept of logos, which he often equates with the idea of presence. Derrida believes that a privileging of speech over writing is a symptom of a more general bias in favor of presence as a foundational term in Western philosophical thought. ${ }^{36}$

*756 One might ask why speech is more 'present' than writing, and why it is more highly valued. Derrida considers several plausible arguments to explain the privileging. First, writing is only a method of representing speech. It was invented as a means of recording what people said. ${ }^{37}$ Writing consists of a series of signs that stand for spoken words. Thus, writing is only a substitute for speech, and an imperfect substitute at that. For example, written language often uses non-phonetic spellings. People who have encountered certain words in writing but not is speech often mispronounce them, and written language occasionally leads to corruptions and alterations in natural forms of speech.

Second, speech is connected more closely to the immediate thoughts of the communicator than is writing. When one hears a person talk, that person's

33 OF GRAMMATOLOGY, supra note 1 , at 34-43, 166-67.

34 Id. at 29-44 (discussing Saussure); id. at 101-268 (discussing Levi-Strauss and Rousseau).

35 Id. at 3; see infra text accompanying notes 53-55.

36 Derrida also speaks of 'phonocentrism,' or the privileging of voice. See, e.g., OF GRAM-MATOLOGY, supra note 1, at 11-12. Phonocentrism normally appears in discussions of the privileging of speech over writing.

37 Speech is prior to writing both culturally and historically. J. GREENBERG, ANTHROPOLOGICAL LINGUISTICS 22-23 (1968). Spoken language arrives in a culture before written language, and to this day there are primitive cultures that have no written language. Id. at 22; see also S. MULLER, THE WORLD'S LIVING LANGUAGES 107, 119 (1964) (most languages in Africa, Indonesia, and New Guinea still unwritten). Thus, speech is a prior, and therefore more fundamental, development in the creation of cultures and civilizations than writing. 
intention is immediately communicated by her speech. ${ }^{38}$ Our understanding is derived not only from words, but also from inflections and tone of voice. Sarcasm, enthusiasm, and a hundred other nuances are immediately apparent when we listen to a person; they are less discernible when the text of a speech has been transcribed. ${ }^{39}$ Thus, the preference for speech over writing is a privileging of presence: The immediacy of meaning in speech is privileged over the mediation of thought that occurs in writing. ${ }^{40}$ Speech is immediate, unambiguous, and sincere; writing is distant, ambiguous, and potentially misleading. ${ }^{4}$

38 Derrida argues that the direct temporal connection between speech and thought leads us to this conclusion. He points out that in French, the expression s'entendre parler means both to hear oneself and to understand oneself. OF GRAMMATOLOGY, supra note 1 , at 98.

39 An old joke illustrates this point. A man walks past a laundry which bears a sign reading: 'My name is Fink/and what do you think/I'll do your wash for free.' Thinking he has spotted a bargain, the man takes his laundry there. The next day, when he returns to pick up his laundry, the proprietor, Mr. Fink, asks for a payment of five dollars.

'Five dollars?' asks the man. 'What about your sign?'

'Can't you read?' replies Fink. 'The sign says: "My name is Fink, and what do you think, I'll do your wash for free?"

The joke seems to demonstrate the capacity of writing to mislead and the superior expressive abilities of speech. However, this joke also undermines the very point that the phonocentrist (the privileger of speech) wants to make, because it was possible, in writing, to express inflection and avoid misunderstanding by using the correct punctuation. Indeed, were it otherwise, no one would understand the joke in its written form. Conversely, if Mr. Fink had spoken his lines in a monotone, he still might have been misunderstood.

40 Indeed, many people prefer to receive information from a lecture rather than by reading because they find it easier to comprehend and assimilate meaning from what a person is saying than from what she has written. The belief that speech is a privileged way of understanding the 'true meaning' of communication is connected to Derrida's notion of logocentrism, or the privileging of presence.

41 Barbara Johnson sums up the privileging of speech over writing:

The spoken word is given a higher value because the speaker and listener are both present to the utterance simultaneously. There is no temporal or spatial distance between speaker, speech, and listener, since the speaker hears himself speak at the same moment the listener does. This immediacy seems to guarantee the notion that in the spoken word we know what we mean, mean what we say, say what we mean, and know what we have said. 
*757 There are additional connections between speech and presence. Normally, a speaker is physically present when she talks to you; in contrast, you may be reading the words written by a person who is far away and perhaps no longer even alive. A person who is speaking to you can be interrupted and asked to clarify what she means. The same cannot be done with the author of a text one is reading. The author is not present, and only the representations of her past thoughts remain on the page.

After identifying all of the characteristics that define writing, and after arguing how they make writing inferior to speech, one can deconstruct the opposition of speech to writing by showing how the arguments 'undo themselves.' One can demonstrate that each identified characteristic of writing is true of speech as well; in other words, speech is a kind of 'writing' that suffers from the same inadequacies attributed to writing.

First, speech itself is only a sign of what is present in a person's mind; it too is only a signifier of thought. A person's true thoughts and real meanings must be mediated through the use of speech. Furthermore, speech can be as unclear and ambiguous as writing, as most persons who have attended a law school lecture can testify.

Second, for speech to function as a signifier, as a sign, speech must be iterable. It must be possible to speak when one does not mean what one says. Speech also can be separated from the speaker and the moment of intention, in both space and time. One can listen to a politician speak over a radio or television, with no chance to stop the speaker and ask for clarification. One can play a recording of a speech by Martin Luther King over and over again; the sounds one hears are no longer connected to the thoughts of a living person. The emotional impact of recorded speech does not come from the presence of living thought in the speech, but only from its efficacy as a signifier of past thoughts, which have long ago faded away.

Derrida thus shows that speech, as a signifier of thought, shares all of the properties that we had associated with writing. Speech is merely a special case of a generalized idea of writing. This 'arche-writing'42 is the iterable representation of a signified by a signifier. Speech and writing (in the normal sense of the word) are both varieties of this more generalized form of 'writing.'

Derrida uses the word 'writing' in this broader sense to stand for three *758 basic properties of signification: (1) the substitution of the signifier for what it signifies; (2) the mediation of the experience of the signified by the signifier,

Johnson, supra note 1 , at viii.

${ }^{42}$ See OF GRAMMATOLOGY, supra note 1 , at 56-57. 
and (3) the iterability of the signifier at different times and in different contexts. ${ }^{43}$ 'Writing,' as used by Derrida, is a paleonym ${ }^{44}$-a word with an old meaning which has had a new meaning grafted on to it. 'Writing' in Derrida's general sense recalls the reversal of the hierarchy of speech over writing from which the broader conception arises. Derrida's project, at least in its initial incarnation, was a call for a science of 'writing,' or a Grammatology, which would investigate and expose the hidden logocentric biases of Western thought. ${ }^{45}$

\section{The Logic of the Supplement}

Derrida also deconstructs the hierarchy of speech over writing through the 'logic of the supplement.' The term 'supplement' comes from Rousseau, who describes writing as a 'supplement' to speech. ${ }^{46}$ Writing is a supplement to speech in that it represents speech. The 'natural' condition of language is spoken; writing is merely added later:

[S]peech being natural or at least the natural expression of thought, ... writing is added to it, is adjoined, as an image or representation. In that sense, it is not natural. It diverts the immediate presence of thought to speech into representation and the imagination. This recourse is not only 'bizarre,' but dangerous. It is the addition of a technique, a sort of artificial and artful ruse to make speech present when it is actually absent. It is a violence done to the natural destiny of the language $\ldots . .47$

However, the word 'supplement' has many meanings. First, it can mean something added to an already complete or self-sufficient thing. For example, I teach out of the latest edition of a constitutional law casebook. The book is finished, complete in itself, but every year the publisher distributes a supplement adding cases decided by the Supreme Court after the date of the casebook's publication. However, the fact that the publisher provides a supplement to my

${ }^{43}$ See id. at 44-45, 55-57; H. STATEN, supra note 1, at 60-61, 121; Limited Inc abc, supra note 1, at 189-90.

${ }^{44}$ See supra note 18.

${ }^{45}$ See Semiology and Grammatology, supra note 22, at 35-36.

46 See OF GRAMMATOLOGY, supra note 1, at 144. Similarly, Rousseau speaks of culture as a supplement to nature and masturbation as a supplement to normal sexual relations. The latter supplement Rousseau refers to as a 'dangerous supplement,' a phrase Derrida seizes upon as characteristic of all supplementation. See infra text accompanying notes 47-48.

47 OF GRAMMATOLOGY, supra note 1, at 144 . 
casebook indicates that the casebook is incomplete as a teaching aid-it needs supplementation to make it complete. $* \mathbf{7 5 9}$ This is the second meaning of 'supplement'-something added to something lacking in order to complete it, as one takes vitamin supplements to achieve a healthy diet.

If writing is a supplement to speech, in the sense that it is added to speech, it may well be dangerous. Writing may infect the naturalness of speech, alter speech, or even supplant it. Some people may begin to speak in the same stylized way in which they write. Writing may lead to mistakes in pronunciation. For example, uneducated French people occasionally pronounce the silent consonants in their language. As time passes, writing may become so important that all official acts are recorded, certain types of oral promises are no longer enforced, and storytellers and town criers are replaced by authors and journalists. Rousseau's life provides an example of the displacement of speech by writing. Rousseau, who exalted the naturalness of speech, was a writer by profession; he is now best remembered not for what he said, but for what he wrote. ${ }^{48}$

Yet, Derrida would argue, writing can only supplement speech in the first sense (representation of speech) if speech can be supplemented in the second sense (having a lack that could be fulfilled). By now we know what that lack is: Speech is not thought made present to the listener, but aural symbols that represent thoughts. Speech only appears to possess 'presence,' or a direct connection to the mind of the speaker because of the fortuity that people speak and think simultaneously. In reality, however, speech-as-thought is a sham; like writing, speech is a mediation of thought, a delaying through representation. It is for that reason that writing can supplement, or take the place of, speech.

Thus, we see a new meaning of the term 'dangerous supplement.' Writing is indeed a dangerous supplement, not because, as Rousseau feared, it might infect the purity of speech, but because the supplementary capacity of writing demonstrates that speech already possesses that which we dislike about writing. It is as if one met a lover's relatives and saw for the first time unpleasant qualities common to the whole family.

From this Derrida wants to make a larger claim: If we thought that speech was present and writing a mere representation of speech, we now see that speech, too, is only a mediation of something more present. Speech, like writing, is a supplement. (Note the crucial move in Derrida's argument: A signifier supplements that which it signifies.) But if speech is a supplement, that which it supplements must also be lacking, for otherwise speech could not represent it. That new thing must, in turn, be a $\mathbf{* 6 0 0}$ supplement (signifier), which represents

48 Writing may be dangerous in still another way. Derrida argues that both Rousseau and Levi-Strauss identified speech with nature and writing with culture. The invention of writing and its introduction to primitive peoples brought a moral and spiritual decline that is closely associated with the corrupting influence of culture upon nature. See id. at 101-40. 
something further, and so on. The result is a chain of supplements, reaching towards an unmediated, complete, self-sufficient presence. 49 To speak the language of signs, the result is a chain of signifiers, each pointing to the next, each reaching towards a pure, unmediated signified..$^{50}$

But now comes the great irony of this logic. The Real Thing, Presence Itself, must, by definition, be something that could not be supplemented or represented by a sign, for it is self-sufficient, and could not serve as a signifier or supplement. The world as we know it is only a world of representations, and representations of representations, ad infinitum. Every signified is actually a signifier in disguise. Derrida describes the ultimate deconstruction of presence:

There is nothing outside of the text .... What we have tried to show by following the guiding line of the 'dangerous supplement,' is that in what one calls ... real life ... there has never been anything but writing; there have never been anything but supplements; substitutive significations which could only come forth in a chain of differential references. . . . [T] he absolute present, Nature, ... ha[s] always already escaped, ha[s] never existed ....51

'Writing' is all there is. This conclusion follows from Derrida's argument that a sign can only represent still another sign. Derrida's famous aphorism il n'y a pas de hors-texte (there is nothing outside of the text) is a metaphor which proclaims that all understanding is metaphorical. ${ }^{52}$ The 'text' of which Derrida speaks is not merely words, but life itself: ' Our very relation to 'reality' . . . functions like a text. ${ }^{53}$

Derrida's critique can be viewed as nihilistic because it appears to deny the existence of objective truth. On the other hand, Derrida's own arguments subtly rely on the notion of truth. The basic claim is that a signifier only imperfectly represents the thing it signifies. This is not a mistake of logic, or an oversight on Derrida's part. We speak in logocentric terms, so that our critique of logocentrism must rely on suspect categories of thought. This is the case with all

49 Cf. id. at 152-57 (describing chain of supplements involved in Rousseau's love object).

${ }^{50}$ Id. at $49-50$.

${ }^{51}$ Id. at $158-59$.

52 Id. at 158.

53 Johnson, supra note 1 , at xiv. 
deconstructions; each uses the conceptual apparatus of the very thing that it wishes to subvert. ${ }^{54}$

*761 Derrida's seemingly nihilistic conclusion must be understood in the context of his method of reaching it. Derrida does not deny the existence of objective truth as much as he affirms the interpretative character of our attempts to comprehend truth. Our 'truth' - the conceptual apparatus we create to explain the world do ourselves - is only a sign or metaphor for an endless succession of still other signs and metaphors, and we have forgotten that it is only that. Thus, the Real Truth seems always beyond our grasp, outside the dominant conceptual apparatus, because that apparatus is necessarily always incomplete and capable of further supplementation.

Our frustation in our attempts to experience the Real Thing, whether we call it 'truth' or 'presence,' stems from the desire in Western philosophy to foundationalize. Here is the agenda of traditional Western philosophy: One can only seek truth if one discovers fundamental principles and builds upon them. ${ }^{55}$ We should recognize this 'agenda' by now as privileging. The act of privileging requires the privileged term to be foundational, complete, self-sufficient; however, it is none of these things. It is related to the non-privileged term in a system of mutual differentiation and dependence, or difference.

${ }^{54}$ Derrida demonstrates the precarious position of the deconstructionist by placing certain concepts sous rature ('under erasure'). For example, he uses the word 'is' with a line through it to show that the word is logocentrically biased ('being' is the ultimate expression of presence) yet necessary for expression. OF GRAMMATOLOGY, supra note 1, at 19.

It should now become clear why explanations of deconstruction necessarily involve a modification of it. My attempt at explanation is a logocentric project. I seek to present the foundations of Derrida's thought in a clear, easily comprehensible, logical progression, beginning with simple ideas and then working to more complicated results. Obviously, there is something paradoxical about using logocentric methods to develop a critique of logocentrism. However, to argue that a logocentric presentation of deconstruction is suspect because it misstates the 'true' content of Derridean thought is simply to engage in another logocentric move, that is, that there is a privileged reading of Derrida, a true unmediated presence, of which all interpretations are inferior copies.

55 OF GRAMMATOLOGY, supra note 1, at 97 (history of metaphysics is history of logocentrism); J. CULLER, supra note 1, at 92-93 (logocentric practice in Western philosophy moves from fundamental ideas to elaboration of ideas); Limited Inc abc, supra note 1, at 236 (single recurrent gesture in Western metaphysics is move from good, positive, pure, simple, and essential to evil, negative, impure, complex, and accidental). 
The privileged concept is incomplete; it is only a supplement, a signifier, a metaphor. For that reason, we are able to use it against itself, to deconstruct it. The act of privileging, of asserting that one of two mutually dependent concepts is really foundational, is like drinking from the springs of the mythical river Lethe, after which we forget our past. Once we have accepted the privileging, we forget that the foundational concept was only a metaphor, a supplement. Deconstruction awakes us from our dogmatic slumber, and reminds us that our 'truth' is only an interpretation.

\section{E. Deconstruction and Ideology}

Although these issues seem metaphysical, we can translate Derrida's concerns into a legal setting. ${ }^{56}$ Legal doctrines both reflect and regulate $\boldsymbol{* 7 6 2}$ social life. The choice of protected rights and of enforcement techniques reflect views, whether obvious or obscure, about social relations. Law tells a story about what people are and should be. ${ }^{57}$

To give an obvious example, laws that permit (or enforce) discrimination on the basis of race or sex tell a different story about people than laws that prohibit such discrimination. The principles of a social theory like Liberalism tell a story about human nature, which some accept and others criticize. ${ }^{58}$ Even the seemingly most insignificant or neutral doctrines and rules, taken as a whole, have a story to tell, if we are willing to listen to them. ${ }^{59}$

56 Note that I am presenting my interpretation of Derrida, which is my own 'dangerous supplement' to his work and my own metaphor.

57 Clare Dalton uses this metaphor in her deconstruction of contract doctrine. Dalton, supra note 2, at 999.

58 For example, it is often asserted that Liberalism's emphasis upon individual autonomy ignores other aspects of human nature, such as the need for communal sharing of values. The vision of human personality and responsibility that Liberalism poses is disputed both by the right and the left. Libertarians argue that Liberals violate principles of self-determination and autonomy by asking people to contribute to a common good, while Marxists argue that Liberal capitalism hides the real nature of relations between worker and capitalist under a veneer of free exchange. Of course, one also can criticize each of these alternatives to Liberalism as portraying a fundamentally false picture of human nature.

59 In her deconstruction, Dalton argues that the ideology of contract law, which privileges the view of contracts as the 'neutral facilitator of private volition,' and is 'concerned at the periphery with the imposition of social duties,' Dalton, supra note 2 , at 1014 , is also present in the doctrines of implied contracts, parol evidence, and consideration. Id. at 1014-24, 1048- 52, 1066-95. She concludes 
We can think of a system of law as a community's attempt to realize human ends. This presupposes a description of the good and bad in human nature: what people want from their lives and what their limitations are. This description necessarily involves privilegings of certain aspects of human nature over others. Later, we justify our system by claiming that it is the best, given the natural constraints of the human condition. For example, an advocate of laissez-faire might argue that, given the natural self- interestedness of people, unregulated market transactions are the best way to realize human goals. But the deconstructive critique reminds us that our social vision and system of laws are not based upon human nature as it really is, but rather upon an interpretation of human nature, a metaphor, a privileging. We do not experience the 'presence' of human nature; we experience different versions of it in the stories we tell about what we are 'really like.' These stories are incomplete; they are metaphors and can be deconstructed. Too often we forget that our systems of law are based upon metaphor and interpretation; we mistake the dominant or privileged vision of people and society for real 'present' human nature, as Rousseau confused speech with the presence of thought. $* \mathbf{7 6 3}$ At the point, the metaphor becomes mistaken for what it describes. But latent within the metaphor is a countervision that can be located and brought to the surface through deconstruction. It exists within the privileged conception because the latter ultimately depends upon it in a relation of differance.

The argument of the laissez-faire advocate presupposes a vision of what is most important about people, and necessarily relegates other aspects of the human condition, such as altruism and community, to marginal status. We could deconstruct this vision of humanity by showing how economic individualism ultimately depends upon social cooperation and the sharing of values. We could show the incompleteness of this vision of human nature, its poverty in describing what people are like and the nature of their relations to each other. A part of humanity will always escape this vision because it is only a metaphor, a signifier. The vision suffers from a lack that needs to be supplemented, and the supplement is a countervision that has been relegated to the periphery. This supplement is indeed 'dangerous,' for it threatens to subvert the picture of human nature posed by the dominant conception. ${ }^{60}$

that although these doctrines in contract law may seem less overtly political in nature than others, such as duress and unconscionability, the same tensions are at work: '[I]n contract doctrine . . a a comparatively few mediating devices are constantly deployed to displace and defer the otherwise inevitable revelation that public cannot be separated from private, or form from substance, or objective manifestation from subjective intent.' Id. at 1113.

60 See supra notes $46-48$ and accompanying text (discussing danger in supplementation). The deconstruction of the philosophy of economic individualism is a favorite topic of the Critical Legal Studies movement. For a classic discussion of the differance between individualism and altruism, see Kennedy, Form and Substance in Private Law Adjudication, 89 HARV. L. REV. 
The deconstruction of legal concepts, or of the social vision that informs them, is not nihilistic. Deconstruction is not a call for us to forget about moral certainty, but to remember aspects of human life that were pushed into the background by the necessities of the dominant legal conception we call into question. Deconstruction is not a denial of the legitimacy of rules and principles; it is an affirmation of human possibilities that have been overlooked or forgotten in the privileging of particular legal ideas.

Any social theory must emphasize some human values over others. Such categorizing necessarily involves a privileging, which in turn can be deconstructed. But the goal of deconstruction is not the destruction of all possible social visions. By recalling the elements of human life relegated to the margin in a given social theory, deconstructive readings challenge us to remake the dominant conceptions of our society. We can choose to accept the challenge or not, but we will no longer cling to our social vision blindly. Nor can we assume that this vision is the 'real essence' of human $\mathbf{* 6 4}$ nature because that would be a claim to have experienced presence, an experience that Derrida denies that we can ever have.

As Robert Gordon has observed, people 'build structures, then act as if (and genuinely come to believe that) the structures they have built are determined by history, human nature, economic law.' ${ }^{\prime 61}$ Deconstruction allows us to see that ideologies are signs or metaphors that describe social life. They are privileged conceptions of social reality; they are supplements, which can in turn be supplemented. Like Derrida's signs, they are not self-sufficient, but ultimately depend upon the very aspects of human life that they deny and from which they differentiate themselves. Every ideology suffers from an elementary lack: its dependence on what it denies, on what it is exalted over. This lack, this differance, is what we seize upon and exploit in a deconstructive reading.

We now see that the legal deconstructor deconstructs ideologies, which are manifested in particular legal doctrines. By challenging what is 'given,' deconstruction affirms the infinite possibilities of human existence. By contesting 'necessity,' deconstruction dissolves the ideological encrustations of our thought.

1685 (1976). Kennedy's famous statement of the 'fundamental contradiction' of social life is a more general expression of differance. Kennedy, The Structure of Blackstone's Commentaries, 28 BUFFALO L. REV. 209, 211-13 (1979) ( '[T]he goal of individual freedom is at the same time dependent on and incompatible with the communal coercive action that is necessary to achieve it. . . [R] elations with others are both necessary to and incompatible with our freedom.').

61 Gordon, New Developments in Legal Theory, in THE POLITICS OF LAW 289 (D. Kairys ed. 1982). 


\section{F. Deconstruction as a Critical Theory}

One might object that a deconstructive reassessment of our legal and social institutions offers us no logical stopping point. If the results of a deconstructive reading can themselves be deconstructed, deconstruction threatens to become an endless series of reversals and counter-reversals. Once again, nihilism seems an unavoidable consequence.

To answer this charge, I would like to compare deconstructive practice (or at least my interpretation of it) to psychoanalysis. Such an analogy is not at all farfetched. The psychoanalyst engages in a process similar in many ways to deconstruction. The psychoanalyst reverses the privileging of the conscious over the unconscious as the explanation of human behavior. ${ }^{62}$ The psychoanalyst also performs a deconstructive reversal by focusing on seemingly marginal or unimportant elements of the patient's experience, such as everyday events, free associations of ideas, and dream material, to understand the deeper connections that are the key to unconscious motivation. 63

*765 Furthermore, both deconstruction and psychoanalysis offer critical theories. ${ }^{64}$ A critical theory may be distinguished by three characteristics. First, the goal of a critical theory is not to develop a series of true factual propositions, but to achieve enlightenment and emancipation. ${ }^{65}$ Second, a critical theory is self-referential; it may be applied to itself or to the process of its application. ${ }^{66}$ Third, a critical theory is confirmed not by a process of

62 Michels, The Basic Propositions of Psychoanalytic Theory, in INTRODUCING PSYCHOANALYTIC THEORY 12 (S. Gillman ed. 1982) (psychoanalysis reverses emphasis on outer world as determinant of human behavior and concerns itself with inner dispositions of individual).

63 See L. KOLB \& H. BRODIE, MODERN CLINICAL PSYCHIATRY $750-55$ (10th ed. 1982); see also F. REDLICH \& D. FREEDMAN, THE THEORY AND PRACTICE OF PSYCHIATRY 276 (1966) ('Free association [involves] full and unedited reporting of mental events, including seemingly trivial or obnoxious details.').

64 In this discussion of critical theory, I follow the ideas developed in R. GEUSS, THE IDEA OF A CRITICAL THEORY 55-95 (1981).

65 Id. at 55.

66 This distinguishes critical theories from other types of theories. For example, Newton's theory about particles in motion is not itself a particle in motion, and therefore, does not refer to or explain itself. Id. By contrast, Marxism as a social theory is potentially self-referential. Id. at 56. It tries to explain not only the connections between a person's beliefs and her relation to 
experimentation and empirical verification, but through a more complicated process of self-reflection. The critical theorist determines whether she has achieved enlightenment and emancipation in terms of knowledge and beliefs she has developed in the course of applying the critical theory. ${ }^{67}$

Psychoanalysis possesses all of the characteristics of a critical theory. Its goal is emancipation of the patient from unfulfilling behavior patterns caused by unconscious repressed material. ${ }^{68}$ This emancipation is achieved by a process of progressive enlightenment: The patient learns how her behavior patterns have been caused by unconscious forces and this, in turn, alters her behavior. ${ }^{69}$ Psychoanalysis is potentially self-referential because the process of analysis itself can be understood and criticized in terms of hidden motivations and desires of the analyst. ${ }^{70}$ Finally, the success of analysis often can only be judged through a process of self- reflection by the patient, aided by the therapist. ${ }^{71}$

Like psychoanalysis, deconstructive readings of texts offer the possibility of emancipation from customary ways of thinking. Deconstruction operates by a momentary reversal of privileging. This reversal alters our $* \mathbf{7 6 6}$

various economic classes in society, but also why a Marxist holds the beliefs that she does.

${ }^{67}$ Id. at $55-56,85-86$.

${ }^{68}$ L. KOLB \& H. BRODIE, supra note 63 , at 748-49.

${ }^{69}$ Id. at $749,755$.

${ }^{70}$ For example, psychoanalytic psychotherapy applies the techniques of analysis to the analyst herself when it addresses mistakes and failures in therapy due to countertransference:

[C]ountertransference reactions arise in the therapist as a result of the patient's influence on the physician's unconscious feelings and have their origin in the latter's irrational projections and identifications. The therapist must not permit his own unconscious feelings and attitudes, aroused during phases of treatment, to intrude in his relations with the patient.

Id. at 752; see also S. LORAND, TECHNIQUE OF PSYCHOANALYTIC THERAPY 209-22 (1946) (discussing countertransference); Peters, Transference, in INTRODUCING PSYCHOANALYTIC THEORY, supra note 62, at 99-101 (same).

${ }^{71}$ See M. BASCH, DOING PSYCHOTHERAPY 36-37, 52, 178 (1980). 
view of the privileging, just as the act of uncovering repressed material liberates the phychoanalytic patient.

As a critical theory, deconstruction can also be a self-referential activity because it can be performed on previous deconstructive readings indefinitely. It is this very property that leads to the charge of nihilism. However, the analogy to psychoanalysis shows us why this charge is ill-founded. We do not think that psychoanalysis is futile because a patient can be psychoanalyzed indefinitely or because the act of psychoanalysis can itself be investigated psychoanalytically. Rather, we believe that the psychoanalyst is performing a meaningful function even though her own work is potentially subject to further psychoanalysis. More importantly, the psychoanalyst and patient may properly decide that the patient has progressed sufficiently to end analysis. Similarly, deconstruction need not continue indefinitely if it has achieved the goals of emancipation and enlightenment.

On the other hand, how is one to tell when these goals have been achieved? There is no foolproof answer to this question for deconstruction, but the same may be said for psychoanalysis. There is simply no mechanical method for the analyst and patient to identify when analysis should end. The decision is an act of self-reflection on the part of both that the patient has been sufficiently enlightened and emancipated from the burdens of repressed material. ${ }^{72}$ Of course, this decision may be questioned on the grounds that it is subjective, that one person's 'enlightenment' may be another's neurosis. However, the analyst and patient are entitled to employ a personal judgment based upon a vision of normalcy and good mental health developed in the course of the analysis. ${ }^{73}$

In the same fashion, the deconstructionist must engage in a process of self- reflection to determine when the insights provided by deconstruction have produced sufficient enlightenment with respect to a view of law, legal doctrine, or human society previously accepted as privileged, natural, or complete. This decision is, of course, a political and moral choice, but it is one informed by insights gained through the activity of deconstruction itself. At the moment the choice is made, the critical theorist is, strictly speaking, no longer a deconstructionist. However, the purposes of engaging in the deconstruction have been served. In both psychoanalysis and deconstruction, the justification of when one should cease analysis may $* \mathbf{7 6 7}$ appear self- supporting, and so it is. But such justification is a characteristic of any critical theory. ${ }^{74}$

72 Id.

73 Cf. F. REDLICH \& D. FREEDMAN, supra note 63, at 277 ('Analysis is essentially an educational process. . . . After a successful analysis, the patient will take with him the ability to introspect . . . with candor and to apply such insights ... to life problems.').

74 See R. GEUSS, supra note 64, at 85-88. Compare Unger, The Critical Legal Studies Movement, 96 HARV. L. REV. 561, 580 (1983) ('Legal doctrine 


\section{G. An Example of a Legal Deconstruction}

At this point it might be useful to give an example of a deconstructive argument in a legal context. I will use an argument by the noted British legal scholar P. S. Atiyah, who is not generally known as a deconstructionist. There is nothing unusual about the appearance of deconstructive arguments in the text of non-deconstructionists; recall Hume's deconstruction of Descartes' cogito. 75

In his Promises, Morals, and Law, ${ }^{76}$ Atiyah argues against a theory of contract that bases obligation upon individual will or intention. Atiyah notes that the commensense view of promissory obligation is that promises are binding because of the intent of the party and its objective manifestation by the act of promising. He suggests that the explicit promise, with its deliberate manifestation of intent, is usually viewed as the paradigmatic case of contractual obligation. The law then attempts to explain the binding nature of implied promises in terms of the standard case of promising:

In law and, I think, with most contemporary writers on philosophy, the traditional explanation of an implied promise assumes that the explicit promise is the paradigm case. The implied promise is then treated as a case where no explicit promise is made in so many words, but where, from his words and conduct, it is plain that the party intends to bind himself. Simple examples . . . concern contracts made by boarding a bus ... or ordering a meal in a restaurant. . . . The lawyer explains these obligations by saying that there are implied promises. ${ }^{77}$

We can already see the hierarchical relationship at work. The paradigmatic case of promissory obligation concerns explicit promises, in which intention is manifested by specific promissory words. Implicit promises are parasitic upon explicit promises: The intention to be bound is manifested $* \mathbf{7 6 8}$

rightly understood and practiced is the conduct of internal development through legal materials.') with J. RAWLS, A THEORY OF JUSTICE 48- 51 (1971) (sense of justice comes from matching initial convictions with proposed reconceptions in attempt to achieve reflective equilibrium). Note that the establishment of a 'reflective equilibrium' creates a new privileging. The defense of the new privileging is a constructive, and not a deconstructive, activity.

75 See supra note 27.

76 P. ATIYAH, PROMISES, MORALS, AND LAW (1981) [hereinafter PROMISES, MORALS, AND LAW].

${ }^{77}$ Id. at 173 (footnote omitted). 
(and thus implied) not by the defendant's words of promise, but by her conduct. Thus, one explains the legal obligation of ordering a meal in a restaurant in terms of previous cases in which people have intended to purchase a meal and have said: 'If you serve me food, I will pay you the price listed on the menu,' or words to that effect. But basing the obligatory nature of implied promises upon explicit promises opens the way for a deconstructive reversal of the hierarchy, a reversal that may tell us something new about why promises are binding:

[T] here are difficulties with this traditional explanation. What of the person who does not intend to pay his fare on boarding the bus, or pay for the meal supplied to him in the restaurant? The lawyer brushes aside this difficulty, appealing to what he calls the 'objective test' of promise or assent. There is the appearance of a promise and that is enough. But this explanation is not very satisfying. For it dismisses what is—on the traditional view - the very central requirement of a promise. If a person who intends to steal a ride on a bus is liable to pay his fare in exactly the same way as the person who intends to pay his fare, it seems odd to say that it is the intention which creates the liability in both cases. ${ }^{78}$

Atiyah's argument calls into question whether it is really the intention that creates the obligation. Indeed, even in the case of explicit promises, we may wonder whether intention creates obligation. Imagine the person who walks into the restaurant and says 'I promise to pay for the food I consume,' when he has no intention of paying. Will his intention not to be bound shield him from moral culpability or legal liability? Indeed, it is precisely because he lacks the intention that he should be made to pay. Atiyah notes that there is something strange about a theory of contractual liability based upon intent:

[T]o imply a promise suggests that it is because of the promise that the relevant party is bound by an obligation. He is obliged to pay for the meal or pay the bus fare because he has promised. However, it seems quite plausible to suggest that the truth is the other way round. It is because he is bound by an obligation that we generally feel impelled to imply a promise. Naturally, if that is right, the source of the obligation cannot lie in the implied promise itself, but must be sought elsewhere. . . . [I]t is often, perhaps always, the case that the conduct itself justifies the creation of the obligation. . . . In the great majority of cases of this nature ... the intention to pay will exist, and so will the intention to assume or accept the legal obligation. But we must never forget the defaulter. *769 Occasionally people do order meals in restaurants without any intention of paying. Nobody doubts-least of all the lawyer - that this makes not the slightest difference to the obligation to pay. ${ }^{79}$

${ }^{78} \mathrm{Id}$.

${ }^{79}$ Id. at $173-74$. 
We may translate this argument into Derrida's terminology. The classical theory contract involves a privileging of explicit promises over implicit promises because in explicit promises the thing that makes the contract bindingthe intention of the actor to enter into an agreement and be bound by it - is in some sense more 'present.' The speaker's explicit promise gives evidence of her 'real' intentions. In the case of an implied promise, these intentions are hidden, and can only be inferred from the circumstances. A theory of implied promises supplements the will theory, which explains the binding nature of explicit promises. The supplementary theory explains why there is a binding obligation when the promisor's present intent is not immediately known to the promisee.

Following the logic of the supplement, however, we can argue that a theory of explicit promises can only be supplemented if explicit promises also defer presence (the present intention of the promisor at the moment of promising). Explicit promises are binding because they manifest intent, but the objective manifestation of intent in an explicit promise is only binding because it acts as a signifier for presence (the promisor's actual will or intent). However, as a sign, the explicit promise must be iterable. Thus, an explicit promise could only bind a promisor if it could bind regardless of the promisor's intent, that is to say, only if the dishonest promisor also could be bound.

Atiyah has argued that this is how the law treats the dishonest promisor. ${ }^{80}$ Promises are binding even if there is no connection between the objective manifestation and the presence of subjective intention. The 'presence' of the promisor's intent at the moment of promising does not create the moral obligation. Rather, we explain the obligation of explicit promises in terms of the reasons implicit promises are binding: They confer a benefit on the promisor that it would be unjust not to repay, or they induce justified reliance on the part of the promisee.

This argument leads to a broader generalization. The privileging of a will theory of contract over a theory based upon effect (unjust enrichment or reliance) involves a relation of differance-of mutual differentation and dependence. A theory that postulates the will of the promisor as binding must explain the moral obligation involved in cases in which the promisor does not will herself to be bound, but accepts a benefit or creates $* \mathbf{7 7 0}$ detrimental reliance to the promisee. Thus, a will theory ultimately depends upon the theory over which it is privileged.

Of course, the relation between privileging of ideas and construction of ideologies gives Atiyah's deconstruction additional importance. Atiyah is an historian as well as a legal theorist, and he recognizes the connection between the

${ }^{80} \mathrm{Id}$ 
will theory and the ideology of the nineteenth century. ${ }^{81}$ Indeed, he argues that a consequence of the privileging of the will theory of contract was the emphasis on purely executory contracts as the paradigmatic case of moral and legal obligation (in contrast to cases of detrimental reliance or unjust enrichment) and the emphasis on the expectation interest as the paradigm of what the law of contracts was designed to protect (as opposed to the reliance or restitution interest). ${ }^{82}$

Needless to say, the law has moved a considerable distance from the nineteenth century model in both respects. What is important for our purposes is that the deconstruction of a privileging in a limited area of contract doctrine exposes a more pervasive underlying ideology, which gave rise to the privileging. Ironically, it also gives us the chance to investigate the unquestioned ideological assumptions in our current doctrines. Thue, the techniques of deconstruction, as a tool for the analysis of past and present ideological thinking, are especially valuable to the legal philosopher or historian.

Atiyah has used the tools of deconstructive practice to criticize the classical will theory of contract. A deconstruction of an opposition, however, cannot by itself establish a new hierarchy in place of an old one, because the new hierarchy also could be deconstructed. This is a point Atiyah neglects, for he wants to argue that reliance and benefit are the 'real' sources of promissory obligation. ${ }^{83}$ In so doing, he wants to establish a new hierarchy. However, a theory of contract based wholly upon benefit or reliance must explain why promises are binding immediately after the parties enter into them, before detrimental effects have developed. Atiyah has great difficulty explaining the binding nature of these promises, and concludes that if they are binding (which he doubts they should be), there are only weak grounds for enforcing them. ${ }^{84}$ His conclusion is not surprising, because the best explanation for the binding nature *771 of these promises is the intent of the two parties to bind themselves, an explanation Atiyah has already rejected. In essence, Atiyah's benefit/reliance theory of promissory obligation must admit its own 'dangerous supplement' to

${ }^{81}$ Id. at 4-5, 7, 33. See generally P. ATIYAH, THE RISE AND FALL OF FREEDOM OF CONTRACT (1979) [hereinafter THE RISE AND FALL OF FREEDOM OF CONTRACT] (historical treatment of nature of contractual and promissory liability).

82 See THE RISE AND FALL OF FREEDOM OF CONTRACT, supra note 81, at 424-29, 441-43, 456; PROMISES, MORALS AND LAW, supra note 76 , at 33 .

${ }^{83}$ More specifically, he argues that the social group has determined that reliance and benefit are the conditions for promissory obligation. PROMISES, MORALS, AND LAW, supra note 76, at 129, 166-67, 193-94.

${ }^{84}$ Id. at $208-12$. 
explain mutually unrelied upon executory promises. This 'dangerous supplement,' of course, is a disguised version of the will theory.

Note the irony: In the classical theory, the purely executory promise was the paradigm case; the implied promise was the exception, and the classical theory had to be supplemented with a theory explaining the binding nature of implied obligations. However, this supplement was a dangerous one, as Atiyah has shown. One might view explicit promises as merely a special case of implied promises; that is, promises whose binding nature lies in socially imposed norms and not in the assumption of individual will. On the other hand, under Atiyah's benefit/reliance theory, the acceptance of benefits or the creation of reliance becomes the paradigmatic case of promissory obligation and the purely executory unrelied upon promise becomes the exception, which must be explained by the use of a supplementary theory of obligation.

Similarly, even Atiyah's basic premise, that promises are binding if there is a pre-existing obligation in the form of a benefit received or detrimental reliance incurred, must smuggle in the will theory through the back door:

Suppose, for example, that A and B 'agree' on the sale of B's house to A for $<<$ PoundsSterling $>>20,000$. A promises to pay the price, and B promises to convey the house. . . . The promises do not simply create obligations, on their own as it were. A's obligation to pay the price will not arise just because he has promised: it will arise if and when he receives a conveyance of the house. B's obligation to convey does not arise just from his promise: it arises if and when he receives the price. . .. If [A] gets the house, he surely has an obligation to pay, irrespective of the promise: it is not A's house, and B has no intention of making a gift ....85

Atiyah argues that $\mathrm{A}$ is obligated because $\mathrm{B}$ has conferred a benefit on him (and therefore A would be unjustly enriched if he did not perform). This raises the question of how we know that $\mathrm{A}$ would be unjustly enriched. Atiyah responds that $\mathrm{B}$ did not intend to make a gift of the house. Thus, Atiyah's benefit/reliance theory of obligation turns upon the intent of B, and we are back to a version of the will theory.

I have not refuted Atiyah's skeptical arguments regarding the will theory $* 772$ of contract. On the contrary, Atiyah's deconstruction of the will theory of contract is quite successful. Atiyah is wrong, however, in thinking that he has shown that a new ground of explanation will succeed where the old one has failed. Rather, he has demonstrated that the will theory and the benefit/reliance theory of promissory obligation exist in a relation of differance, that is, of mutual differentiation and dependence. This conclusion is unsatisfying to someone who

${ }^{85}$ Id. at 189-90 (emphasis added). 
seeks an ultimate ground for contractual obligation, but Derrida's work suggests that this is the best that can be done.

\section{THE LIBERATION OF TEXT FROM AUTHOR}

\section{A. Readings and Misreadings}

Derrida's conclusion that there is only 'writing,' that there are only signs and metaphors for still other signs and metaphors, has interesting consequences for a theory of interpretation. These consequences are important to lawyers, who are greatly concerned with the interpretation of texts.

I want to introduce these ideas with a simple paradigm of textual interpretation. According to this simple paradigm, a text is a representation of an author's intent. Thus, a novel represents a story (and artistic ideas) that a novelist wishes to express. A philosophical treatise represents ideas that a philosopher wishes to convey. A judicial opinion stands for the principles of decision that are used to decide a case. The goal of interpretation is understanding the meaning of the text, that is, the author's intent. If we interpret correctly, we grasp the author's intent; if we interpret incorrectly, we miss the author's intent.

This simple paradigm of interpretation is not a popular theory of interpretation among literary critics these days. ${ }^{86}$ However, the simple paradigm of interpretation continues to be well-respected among legal thinkers as a preferred method of interpreting legal texts. Indeed, if most lawyers or judges were asked how statutes or judicial decisions should be interpreted, they would probably respond that the author's intent is the most *773 important factor. ${ }^{87}$ As I

86 Indeed, the reader-response movement in literary criticism has championed the role of the reader in constructing the meaning of texts. See generally S. FISH, IS THERE A TEXT IN THIS CLASS? (1980); S. MAILLOUX, INTERPRETIVE CONVENTIONS: THE READER IN THE STUDY OF AMERICAN FICTION (1982); THE READER IN THE TEXT (S. Suleiman \& I. Crosman eds. 1980); READER-RESPONSE CRITICISM (J. Tompkins ed. 1980). Only a few literary critics, such as E. D. Hirsch, still hold to the view that the author's intent is the primary source of interpretation. See, e.g., E. D. HIRSCH, THE AIMS OF INTERPRETATION (1976); E. D. HIRSCH, VALIDITY IN INTERPRETATION (1967).

Of course, the argument that the primary source of meaning lies in the reader's response rather than in the author's intention involves a privileging as much as the reverse claim, and therefore, is equally subject to deconstruction. The relation between author and reader is one of differance.

87 'Although there have been occasional heretics, it is an article of faith among American lawyers that the function of a court when dealing with a statute is to ascertain and effectuate the intent of the legislature.' Murphy, Old Maxims Never Die: The 'Plain-Meaning Rule' and Statutory Interpretation in the 'Modern' 
shall argue later, the strong hold that the theory of authorial intent has upon legal thinkers probably arises from its association with the principle of the Rule of Law. ${ }^{88}$

I would now like to give a particular example of how the simple paradigm of interpretation operates in a legal setting. Suppose that Brown v. Board of Education ${ }^{89}$ had just been decided. A black janitor files suit in a federal district court in Mississippi, contesting a 'coloreds only' seating section in a cafeteria at a municipal office building. The district court must decide whether Brown (and the text of the Fourteenth Amendment that it interprets) outlaws the maintenance of 'separate but equal' dining facilities in an establishment operated by a municipal government. According to the simple paradigm of interpretation, if

Federal Courts, 75 COLUM. L. REV. 1299, 1299 (1975) (footnote omitted); see also R. DICKERSON, THE INTERPRETATION AND APPLICATION OF STATUTES 36 (1975) (same); J. HURST, DEALING WITH STATUTES 32- 40 (1982) (fundamental principle of statutory construction is inquiry into legislative intent); 2A N. SINGER, STATUTES AND STATUTORY CONSTRUCTION ' 45.05, at 20-22 (Sands 4th ed. 1984) ('An overwhelming majority of judicial opinions considering statutory issues are written in the context of legislative intent.'). Although Professor Murphy expresses the prevailing view, the number of 'heretics' is greater than his quotation suggests. See, e.g., Radin, Statutory Interpretation, 43 HARV. L. REV. 863 (1930) (legislative intent fictional and irrelevant concept); H. Hart \& A. Sacks, The Legal Process 1410 (tent. ed. 1958) (unpublished manuscript) (legislative purpose created by courts and not identical with intent).

In constitutional law, where there is perhaps the greatest controversy about proper methods of textual interpretation, the simple paradigm remains surprisingly strong. E.g., R. BERGER, GOVERNMENT BY JUDICIARY (1977); Bork, Neutral Principles and Some First Amendment Problems, 47 IND. L.J. 1 (1971); Monaghan, Our Perfect Constitution, 56 N.Y.U. L. REV. 353 (1981). Even more liberal authors often pay lip service to the principle of authorial intent. Ronald Dworkin, who argues that the Framers' intent is not a psychological fact to be discovered but only something to be invented, still makes an obeisance to the simple paradigm when he proposes that one should look to the Framers' general abstract concepts of 'due process' and 'equal protection,' rather than to specific concrete conceptions of these ideas in practice. Dworkin, The Forum of Principle, 56 N.Y.U. L. REV. 469, 477, 488-91, 497 (1981).

${ }^{88}$ See infra text accompanying notes 108-09.

89347 U.S. 483 (1954). 
the court holds one way, it has read Brown correctly, while if it holds another way, it has misinterpreted or misapplied Brown. ${ }^{90}$

It is possible to distinguish Brown on the ground that it applies only to schools, where impressionable children will be greatly affected by the perception of separate treatment. This is a possible interpretation of Brown, and I mention it because it is important to understand that distinguishing a case is as much an interpretation as following it. On the other hand, following the simple paradigm of interpretation, this reading may misinterpret Brown because the authors of Brown intended that all separate but $* \mathbf{7 7 4}$ equal public facilities for blacks and whites should be considered presumptively unconstitutional.

The simple paradigm of interpretation involves a privileging. There are many possible reading of Brown $\mathrm{v}$. Board of Education, and these readings can take place in a multitude of different factual and legal contexts. However, some of these readings are correct, and others are incorrect. Incorrect reading are mistakes of legal reasoning, which should be eliminated from a legal system to the greatest extent possible. The commonsense understanding of legal reasoning, then, is premised upon a distinction between readings and misreadings of legal materials. Therefore, the goal of good legal interpretation is to separate the correct readings from the incorrect readings. .1

Now this privileging of readings over misreadings can be deconstructed. Culler's treatment of the subject, although it does not specifically concern legal texts, is excellent:

When one attempts to formulate the distinction between reading and misreading, one inevitably relies on some notion of identity and difference. Reading and understanding preserve or reproduce a content or meaning, maintain its identity, while misunderstanding and misreading distort it; they produce or introduce a difference. But one can argue that in fact the transformation or modification of meaning that characterizes misunderstanding is also at work in what we call understanding. If a text can be understood, it can in principle be understood repeatedly, by different readers in different circumstances. These acts of reading or understanding are not, of course, identical. They involve modifications and differences, but differences which are deemed not to matter. We can thus say, in a formulation more valid than its converse, that

90 This statement is true not only of the simple paradigm. Many other theories of interpretation label readings as proper or improper, although they might reach different results in individual cases.

91 Again, even if one did not subscribe to the simple paradigm of interpretation, it still might make sense to speak of correct and incorrect interpretations of legal texts. One would not even have to claim that there was only one correct interpretation to speak in this way. 
understanding is a special case of misunderstanding, a particular deviation or determination of misunderstanding. It is misunderstanding whose misses do not matter. The interpretive operations at work in a generalized misunderstanding or misreading give rise both to what we call understanding and to what we call misunderstanding.

The claim that all readings are misreadings can also be justified by the most familiar aspects of critical and interpretive practice. Given the complexities of texts, the reversibility of tropes, the extendability of context, and the necessity for a reading to select and organize, every reading can be shown to be partial. Interpreters are able to discover features and implications of a text that previous interpreters neglected or distorted. They can use the text to show that previous readings are in fact misreadings, but their own readings $* 775$ will be found wanting by later interpreters, who may astutely identify the dubious presuppositions or particular forms of blindness to which they testify. The history of readings is a history of misreadings, though under certain circumstances these misreadings can be and may have been accepted as readings. 92

Lawyers' readings of cases are partial in two senses of the word. First, they are partial in Culler's sense, in that they represent only some aspects of the meaning of texts. They are also partial in a second sense, in that they are interpretations that benefit (and thus are partial to) the position they advocate. Certainly, the second kind of partiality is likely to lead to the first. The interpretations of judges are no less partial in either sense of the word. The materials of the law-cases, constitutions, and statutes - take on new meanings as legal contexts change. Throughout history, interpretations are constantly offered, some of which are later labelled misreadings. The history of the law is iteration; the development of law is the development of legal materials, which are subjected to new interpretations as we read them over and over again in different factual, historical, and political contexts.

The deconstruction of the opposition of readings and misreadings is at first troubling to lawyers because our legal system seems to depend upon the ability to distinguish readings from misreadings. If all readings of legal materials are actually misreadings, then law cannot be a rational enterprise and the Rule of Law is impossible to achieve. Before reaching this conclusion, however, we should consider exactly what the deconstruction of the understanding/misunderstanding privileging has accomplished. Once again, Culler's thoughts on the matter prove instructive:

92 J. CULLER, supra note 1, at 176. The same arguments may be applied to my interpretation of Derrida in this Article. By interpreting Derrida, I present his ideas in a necessarily selective and ordered fashion. My reading of Derrida is partial, and therefore, may be classified as a 'misreading' in the more general sense Culler describes. However, to use Culler's phrase, I would argue that it is a misreading whose misses do not matter much. 
Attacks on deconstructionists ... frequently emphasize that if all reading is misreading, then the notions of meaning, value, and authority promoted by our institutions are threatened. Each reader's reading would be as valid or legitimate as another, and neither teachers nor texts could preserve their wonted authority. What such inversions do, though, is displace the question, leading one to consider what are the processes of legitimation, validation, or authorization that produce differences among readings and enable one reading to expose another as a misreading. In the same way, identification of the normal as a special case of the deviant helps one to question the $* \mathbf{7 7 6}$ institutional forces and practices that institute the normal by marking or excluding the deviant.

In general, inversions of hierarchical oppositions expose to debate the institutional arrangements that rely on the hierarchies and thus open possibilities of change-possibilities which may well come to little but which may also at some point prove critical. ${ }^{93}$

Put another way, the deconstructive reversal has not demonstrated that all readings of Brown v. Board of Education are equally legitimate, but rather has called into question the ways in which we decide that a given interpretation of Brown is illegitimate. This issue is important for two reasons. First, our justifications of what are 'proper' interpretations of a text are not always consistent. ${ }^{94}$ Second, our method of privileging interpretations as appropriate or

93 Id. at 179.

${ }^{94}$ For example, there are clauses of the Constitution we would probably read quite literally, confining our interpretations to the plain meaning of the words. E.g., U.S. CONST. art. II, ' 1, cl. 5 (president must be at least 35 years old). Other clauses, like the equal protection clause, are more ambiguous and require a fuller theory of interpretation, which would no doubt be more controversial. In still other cases, we read the Constitution in ways clearly at odds with the ordinary meaning of its language. The Eleventh Amendment, for example, literally bans all suits, in law or equity, against a state by citizens of another state. U.S. CONST. amend. XI. Yet the amendment is most often invoked to bar suits by citizens against their own state, e.g., Edelman v. Jordan, 415 U.S. 651 (1974). Suits in equity against a state are permitted through the fiction of suing a state officer in her official capacity, e.g., Ex Parte Young, 209 U.S. 123 (1908); suits for monetary damages are permitted if the relief sought is prospective rather than retrospective, e.g., Edelman, 415 U.S. at 664, 668. Even suits for retrospective relief in the form of damages are permitted, if the state is held to waive its immunity. Id. at 671-74.

Ironically, the rule for determining waiver is that a state will be deemed to have waived its immunity 'only where stated 'by the most express language or by such overwhelming implications from the text as [will] leave no room for any other reasonable construction." Id. at 673 (quoting Murray v. Wilson Distilling 
inappropriate is often tantamount to deciding a legal issue. It becomes the process by which we formulate legal doctrine, and will serve to foster or foreclose later doctrinal developments.

We may make a comparison here with the use of deconstruction to privilege legal concepts informed by ideological thinking. Just as deconstruction does not prove the bankruptcy of all social visions but rather affirms the many possible characterizations of social life, so too the deconstruction $* 777$ involved here is designed to create possibilities for interpretation rather than to foreclose them. In introducing deconstructive strategies to texts it cannot be stressed too much that freedom and nihilism are not the same thing.

The deconstructive critique of the privileging of reading over misreadings does have a further consequence, which may at first prove unsettling to lawyers: The simple (or intent-based) theory of interpretation of legal texts is necessarily incomplete. However, as I will now show, this consequence is actually necessary for the Rule of Law to operate in the manner we think it should.

\section{B. The Free Play of Text and the Rule of Law}

Someone says to me:

'Show the children a game.' I teach them gaming with dice, and the other says 'I didn't mean that sort of game.' Must the exclusion of the game with dice have come before his mind when he gave me the order? ${ }^{95}$

Co., 213 U.S. 151, 171 (1909)). This interpretative principle is quite at odds with the principles used to interpret the Eleventh Amendment itself.

Our use of different methods of reading constitutional and statutory texts does not necessarily mean that we are contradicting ourselves. We could defend different hermeneutical principles for interpreting waiver under the Eleventh Amendment and for interpreting the amendment itself on the grounds that the rules for statutory interpretation must be different from those for divining the meaning of the Constitution. A similar explanation could be developed to show why the Eleventh Amendment should be interpreted differently than other clauses of the Constitution. Rather, doconstruction calls these interpretative practices into question and requires us to articulate a political and legal theory to explain the differences. This process also may cause us to reevaluate our hermeneutical practices. Compare Atascadero State Hosp. v. Scanlon, 105 S. Ct. 3142 (1985) (defending current Eleventh Amendment doctrines on general grounds of preserving federalism) with Edelman, 415 U.S. at 687- 88 (Brennan, J., dissenting) (Eleventh Amendment immunity should be restricted to cases falling within its literal meaning: suits against a state brought by citizens of another state).

95 L. WITTGENSTEIN, PHILOSOPHICAL INVESTIGATIONS ' 70 (1953). 
One of the most important ideas that Derrida's work demonstrates is that if (as everyone thinks) we mean more than we say, we also say more than we mean. Our words seem to perform tricks that we had not intended, establish connections that we had not considerred, lead to conclusions that were not present to our minds when we spoke or wrote. Students of statutory construction and the law of contracts are no doubt familiar with many examples of this phenomenon. This curious habit of our words to burst the seams of our intentions and to produce their own kind of logic is what Derrida labels the free 'play' of text. ${ }^{96}$

For Derrida, what we did not intend to say is as interesting as what we did intend. That is why so much of his work makes use of puns, or investigates how what a text says refers to itself or what it does. Much of deconstructive criticism involves the discovery of unintended connections between words. One reason for looking for such connections is that they may condense or crystallize important ideas that are already present in a text. (This is one reason we find slogans and aphorisms so effective in conveying ideas.) But there is a more important reason to investigate the unintended connections between the words in our texts. It is simply a $\mathbf{* 7 8}$ logocentric bias on our part to think that the most important meanings in a text are those the author intended to put there.

In literature, the critic does not think less of her interpretation of Moby Dick because Melville did not see the same connections as he composed his work. A philosopher does not think less of her critique of the Phaedo when she discovers a connection between ideas that Plato did not recognize in his text. Indeed, there is generally great critical importance in discovering that a text says more than the author meant it to say, or that the logic of a text leads to an unexpected difficulty or contradiction. Often, hidden flaws or strengths in a work of literature or philosophical treatise only become apparent over time. Legal texts, like other texts, often present later readers with new meanings, connections, and difficulties that their creators did not contemplate. These meanings are unconvered by the interpretations of successive readers in different historical and cultural contexts.

These are two different reasons that one might be concerned with unintended connections. The first is not Derrida's purpose, although the second is. One might use unintended meanings in a legal text to criticize the reasoning of the author. In her dissent in City of Akron v. Akron Center for Reproductive

96 See, e.g., WRITING AND DIFFERENCE, supra note 1, at 292 ('Play is the disruption of presence.'). A more trivial, yet classic, example of unexpected connections between words is the common pun. Derrida's work often relies on puns to emphasize connections among ideas in a text. See, e.g., DISSEMINATION, supra note 1, at 65-171, 173-285 ('Plato's Pharmacy' and 'The Double Session'). 
Health, ${ }^{97}$ Justice O'Connor argued that the viability-based doctrine of Roe v. Wade $^{98}$ would self-destruct as the point of the fetus' viability came earlier and earlier during pregnancy while technology assured that the time at which abortions were virtually risk free to the mother came later and later. ${ }^{99}$ This consequence of the Roe decision was not envisioned by its author, Justice Blackmun, and Justice O'Connor believed that this unintended consequence was an important criticism of the logic of Justice Blackmun's opinion.

On the other hand, the discovery of unintended connections and difficulties may not involve any criticism of the author at all. A good example is our current understanding of the equal protection clause. The drafters of the equal protection clause probably did not contemplate that one day its words would strike constitutional scholars and judges as requiring equality between men and women. However, when we read the equal protection clause today, with an expansive notion of equality that would have greatly upset the framers of that amendment, we do not mean to $\mathbf{* 7 9}$ criticize their choice of words. Indeed, we demonstrate how their linguistic commitment to equality has brought us to a deeper political commitment to equality. We celebrate the manner in which the authors' words have worked themselves pure in spite of the authors' intentions.

When Derrida hunts for unseen connections in a text, he is usually not attempting to discover errors in the thought of the author. His is not the sort of task that Justice O'Connor undertook in the Akron case. Instead, he is looking for the type of connections that no author can avoid because no author intends them. Derrida seeks to understand the gap between what the author commands by her language and what the language performs - the uncontrollable incongruity in human language and thought. As Barbara Johnson explains, 'the deconstructive reading does not point out the flaws or weaknesses or stupidities of an author, but the necessity with which what he does see is systematically related to what he does not see.'100

97462 U.S. 416, 458 (1983) (O'Connor, J., dissenting).

98410 U.S. 113 (1973).

99

The Roe framework . . . is clearly on a collision course with itself. As the medical risks of various abortion procedures decrease, the point at which the State may regulate for reasons of maternal health is moved further forward to actual childbirth. As medical science becomes better able to provide for the separate existence of the fetus, the point of viability is moved further back toward conception.

462 U.S. at 458.

100 Johnson, supra note 1 , at $\mathrm{XV}$. 
There is an important connection between the principle of the 'free play' of text and Derrida's theory of the sign. For Derrida, a sign can only signify to the extent that it can signify repeatedly, in a number of different contexts. The essential property of the sign is its iterability. It follows from Derrida's theory of the sign that we can use signs if and only if they are separable from our intent-if and only if they 'mean' whether or not they mean what we intend. Thus, if I write a heartfelt love letter to my girlfriend, in order to communicate my most deeply felt sentiments through language, it must also be possible for the same words to be written insincerely, in jest, or even through random creation by a computer program. Language can signify only if it can escape the actual present meaning it had to the person who used it. 101

This surprising conclusion stems from the fact that signs can only be used for communication if they are public. They must be capable of repetition and manipulation by any possible user. ${ }^{102}$ But the public nature of communication necessitates that sign signify repeatedly, regardless of the presence or absence of a present meaning that informs them. A piece of graffiti continues to signify as long as it remains on the wall. Thus, to the extent that B can understand A, it is A's (iterable) signs, and not A's intention, which permits this understanding.

Moreover, the essence of the sign, iterability, carries with it the notion of a repetition of the same in a different context. Language can only operate to *780 the extent that it is repeatable, but language is repeatable only to the extent that what A says means something, albeit not identical to what A meant, to another person B. According to Derrida:

[I]t belongs to the sign to be legible, even if the moment of its production is irremediably lost, and even if I do not know what its alleged author-scriptor meant consciously and intentionally at the moment he wrote it, that is[,] abandoned it to its essential drifting .... [B]y virtue of its essential iterability[,] one can always lift a written syntagma from the interlocking chain in which it is caught or given without making it lose every possibility of functioning, if not every possibility of 'communicating,' precisely. ${ }^{103}$

The structurlal precondition of the sign is its ability to break free from the author, and to mean other than what the author meant. The very act of 'meaning' something creates a chasm between the sign and the producer's intention. This detachability makes interability, and thus intersubjective meaning, possible. The repetition of the sign in the new context is simultaneously a relation

${ }^{101}$ See MARGINS OF PHILOSOPHY, supra note 1, at 317.

102 Id. at 315.

103 Id. at 317. 
of identity and difference; the repeated sign is syntactically identical, yet semantically different. The result is that the text, as it is repeatedly understood, takes on a life of its own in a relation of differance with the person who 'meant' it:

[A]t the very moment when someone would like to say or to write, 'On the twentieth . . . etc.,' the very factor that will permit the mark (be it psychic, oral, graphic) to function beyond this moment-namely the possibility of its being repeated another time-breaches, divides, expropriates the 'ideal' plenitude or self-presence of intention, of meaning (to say) and, a fortiori, of all adequation between meaning and saying. Iterability alters, contaminating parasitically what it identifies and enables to repeat 'itself'; it leaves us no choice but to mean (to say) something this is (already, always, also) other than what we mean (to say) .... ${ }^{104}$

Derrida's aphorism, 'iterability alters, ${ }^{105}$ is a shorthand way of saying that once the signifier leaves the author's creation and is let loose upon the world, it takes on a life of its own in the other contexts in which it can be repeated. ${ }^{106}$ The liberation of the text from the author at the moment of creation results in the free play of the text.

${ }^{104}$ Limited Inc abc, supra note 1, at 200.

105 Id. Derrida also makes a pun on the two possible origins of the word 'iterable': 'iter-,' or 'again,' comes from the Sanskrit 'itera,' or 'other.' The philological ploy suggests that repetition differentiates even as it imitates. Id.

106 Under the simple theory of interpretation, we might still insist that the text has a meaning independent from its context: a clearly definable 'core' of meaning that cannot be varied by context. According to this theory, context affects only the 'peripheral' meanings of the text while preserving the 'core.' Thus, context is only supplementary to the basic, unchanging meaning of the text.

The 'core/periphery' distinction can be deconstructed by noting that the 'core' depends as much on the context as the 'periphery' does. Both the core and the periphery are context dependent. The core meaning of the word 'cow' provides a simple example. If two parties have adopted a code for contracts involving livestock where 'cow' means 'horse,' the core meaning of 'cow' will shift radically. This may look like a trick, but it is the 'normal' context in which we use the word 'cow' that gives us its 'core' meaning.

In Derrida's terminology, context is a dangerous supplement to the meaning of a text. 'Context' indicates both that which accompanies the text (conas in convocation) and that which is posed against the text, or which the text is read against (con- as in contra). Both readings are important, for the text is both dependent upon and differentiated from its context. Text and context thus exist in a relation of differance. There is no text without a context. 
*781 Moreover, if the meaning of a signifier is context bound, context is boundless - that is, there are always new contexts that will serve to increase the different meanings of a signifier. ${ }^{107}$ This should come as no surprise to a legal thinker: The words in a statute or in a case used as precedent take on new meanings in new factual contexts, and cannot be confined to a limited number of meanings. There are an indefinite number of possible contexts in which a given legal text could be read. For this reason, a text is always threatening to overflow into an indefinite number of different significations. ${ }^{108}$

Most of us assume that the Rule of Law requires that legal materials will be essentially determinate in meaning; that there will be a privileged interpretation of a legal text. If a text had many meanings, and no one 'authentic' or privileged meaning, it would be impossible to treat like cases alike according to general and knowable universal principles equally applicable to all citizens. Moreover, if a text had many equally valid interpretations, no interpretation could have an exclusive claim to legitimacy and command the respect of all citizens.

The simple theory of interpretation seems to offer us just such a privileged interpretation. It provides that the privileged interpretation of a legal text is the one consistent with the intention of the author who created it. The simple theory has two advantages. First, it avoids the uncertainty and arbitrariness that would follow if all interpretations were equally valid. It creates the possibility of a single, knowable interpretation of legal materials, which can be applied in a non-arbitrary fashion to all citizens. $* \mathbf{7 8 2}$ Second, the simple theory establishes the legitimacy of the interpretation, for it adopts the meaning of the author (judge, framer, or legislator) who had the authority to create the legal text in the first place. Thus, at first glance, the Rule of Law appears to reject the idea of the free play of text and to embrace instead the simple theory of interpretation: The meaning of a legal text is the meaning of its author, which does not change as the text is introduced into new factual situations or contexts.

${ }^{107}$ See J. CULLER, supra note 1, at 123-28.

108 I use the word 'indefinite' and not 'infinite.' What is important is not the number of possible new contexts, but their unexpectedness. Theoretically, it always should be possible to derive an infinite number of meanings from a text if we are willing to acknowledge all sorts of bizarre ways of reading the text. However, some of these contexts are probably irrelevant in the further context of our legal institutions. (For example, one might look for meanings in a legal text by searching for hidden anagrams that stated a rule.) Although we can be sure that some contexts will be irrelevant, we cannot predict which contexts will be relevant in the future. The number of such contexts may not be infinite, but it is indefinite. We cannot create an all- inclusive list in advance. To use an earlier example, what makes the equal protection clause uncanny in its moral force is the unexpected nature of classifications we may come to see in time as requiring equal treatment or permitting differential treatment. 
However, the grounding of the Rule of Law on the privileging of the author's intent can be deconstructed, and then we see that the relation of the Rule of Law to the author's intent is not so unambiguous. We discover that the Rule of Law must also depend upon the free play of legal texts, an idea which bears a relationship of differance to the simple theory of interpretation.

Let us consider, as an example, a published opinion of a judge appearing in a case reporter. What is the legal effect of this opinion on subsequent cases? The simple theory of interpretation would suggest that (if the precedent is binding) what the judge/author intended is the principle that controls succeeding cases. However, this will not do. The intent of the author does not control, but rather the interpretation of the author's intent as derived by subsequent readers of the text controls. It is the text as read, and not the text as written, that becomes the law.

The principle of iterability explains this result. The Rule of Law cannot operate unless legal materials (which in theory, are what bind persons) are iterable. The Rule of Law presupposes that the same corpus of legal materials will be applied to case A as to case B. If a different rule were applied in each case we would not have the Rule of Law. ${ }^{109}$ However, the author's present intent when she creates legal materials is not iterable; it is forever lost at the moment of creation. All that remains is the sign, the existence of which makes intersubjective communication possible. The iterability of the sign of the author's intent, and not the intent itself, is essential to the operation of the Rule of Law.

In addition, the Rule of Law is based upon the premise that it is not the individual wills of people that control, but laws passed by elected representatives or case law construed and developed by judges. Rule by the arbitrary will of persons would violate the Liberal principle of autonomy; 110 social coercion is not achieved according to arbitrary will, but according $* \mathbf{7 8 3}$ to general, equally applicable rules. Once the rules are established by the governing authority, the rules constitute the authority for deciding cases. Thus, the Rule of Law presupposes that texts rule, and not the persons who created them.

Of course, in deciding the proper application of the rule, we look to the purpose of the governing body that created it. However, that body may not have

${ }^{109}$ I pass over the obvious difficulty that the corpus of laws is constantly changing, so that if case B appears later in time than case A, different legal rules may apply to it. This is a problem for the theory of the Rule of Law, not for my deconstruction.

110 The principle of autonomy holds that persons should be free from coercion by the arbitrary will of another. See F. HAYEK, THE CONSTITUTION OF LIBERTY 139-40 (1960). Recognition of legal rights according to the Rule of Law preserves this principle by preventing inconsistent and arbitrary treatment of persons. Id. 
had a single purpose or it may not have explicitly considered the factual situation at issue. Indeed, many of the legislators may not have read the measure thoroughly before voting on it.

The 'purpose' used by a legal interpreter or decisionmaker is not the pure present purpose of the creator of the legal text. Instead, it is a constructed purpose: a reading of the text (a statute or decision) and of other texts (legislative history) in a particular context. The 'purpose' that we discover and use in the application of a legal rule comes from texts, and not from the author.

Moreover, the Rule of Law requires that a legal text be separated from the purpose present in the mind of the creator of the text. As an example, suppose that airlines lobby for the passage of a law that sets minimum prices for airfares. Assume that legislator A voted for the bill in return for a favor from legislator B. This is not the kind of purpose that a judge can use to construe a statute's operation in a particular context. Nor could A's intent to receive a bribe in exchange for a vote be properly considered. The Rule of Law ultimately relies upon a distinction between proper and improper interpretive purposes. This distinction, in turn, can be deconstructed, but my point here is that the decisionmaker who seeks a purpose must reconstitute, reconstruct, or interpret a purpose from still other interpretations or signs. She must separate those purposes which are 'appropriate' from those which are inappropriate. This act of discovery is an interpretation and deferral of 'presence,' i.e., the purpose 'present' to the mind of the creator of the legal text at the time of its creation, and indeed, may even be a rejection of it.

Another example may prove instructive. Assume that the sole purpose of price control regulation is to benefit the airline industry. After intense lobbying, the legislators are convinced that they need to outlaw 'cutthroat competition' among the airlines. Suppose that economic conditions then change, and the airlines will lose revenue unless they can increase volume by dropping their prices below the minimum price levels. We would not read the statute to mean that minimum prices no longer control, even though that would achieve the authors' purpose of benefiting the airline industry. Rather, we must admit that the text of the statute has taken on a life of its own, apart from the original purpose of the legislators who created it.

*784 The statute's claim to legal authority is derived not from the intent of its framers, but from its present signification. The institutional rules that give binding authority to acts of government recognize the sign (the text) and not the signified (the purpose). The Rule of Law presupposes that the only legitimate solution to the change in economic conditions is to pass a new statute repealing the old price support legislation. ${ }^{111}$

111 The same arguments apply to the interpretation of judicial opinions. If the simple theory of interpretation were required by the Rule of Law, we might be tempted to try to solve today's difficult problems of constitutional law by communicating with the spirit of Chief Justice Marshall, and by asking him what 
The simple theory of interpretation is a logocentric theory, relying upon the 'presence' of the author's intent at the moment of textual creation. By deconstructing, or 'ungrounding' it, we see that the Rule of Law depends upon the free play of text, as much as it depends upon the author's intent. From this deconstruction emerge two mutually differentiated and dependent visions of interpretative practice:

The one seeks to decipher, dreams of deciphering a truth or an origin which escapes play and the order of the sign, and which lives the necessity of interpretation as an exile. The other, which is no longer turned toward the origin, affirms play and tries to pass beyond [the] man . . . who . . . [-]throughout his entire history-has dreamed of full presence, the reassuring foundation, the origin and the end of play ....

There are more than enough indications today to suggest we might perceive that these two interpretations of interpretation-which are absolutely irreconcilable even if we live them simultaneously and reconcile them in an obscure economy-together share the field which we call, in such a problematic fashion, the social sciences.

For my part, although these two interpretations must acknowledge and accentuate their difference and define their irreducibility, I do not believe that today there is any question of choosing - in the first place because here we are in a region (let us say, provisionally, a region of historicity) where the category of choice seems particularly $* \mathbf{7 8 5}$ trivial; and in the second, because we must first try to conceive of the common ground, and the differance of this irreducible difference. ${ }^{112}$

exactly he meant in Marbury v. Madison, 5 U.S. (1 Cranch) 137 (1803). However, I hope that the reader will find something odd about this solution, aside from the idea that judges should be performing seances or raising the dead. Like the Constitution itself, Marbury as text has meanings that live on independently of the meanings of its creator. Therefore, even the author of the text, were he here to communicate with us, would not have a monopoly on the 'real' meaning of Marbury. Rather, we understand intuitively that the author has already had his 'bite at the apple.' Once he has expressed himself, it is the opinion that binds future judges. This, too, is necessary consequence of the Rule of Law.

Of course, if a Supreme Court Justice writes an opinion, she does, in a sense, have a 'second bite at the apple' because she will be able to vote for subsequent applications of the original opinion. But her interpretation of her own writing will not be conclusive; she will have to convince four other Justices. The point is easier to understand if one considers a Justice who retires after writing a given opinion. In subsequent cases, it would be inappropriate to ask her what she meant in her opinion and to accept her views as binding.

112 WRITING AND DIFFERENCE, supra note 1, at 292-93. 
The purpose of the deconstruction is not to establish that any interpretation of a text is acceptable, but that the yearning for originary meaning in the simple theory of interpretation is incomplete and cannot serve as a foundation for interpretation. We must, to some degree, acknowledge the free play of the text. However, as Derrida notes above, there can be no question of choosing the free play of legal texts as a new ground for interpretative practice, a fact that critics of original intent theory may too easily forget. The intent theory and a theory of free play must coexist in an uneasy alliance in which neither can be master nor servant. The relation of differance between them prevents either from serving as an originary ground of interpretative practice.

Of course, I have only considered two possible approaches to interpretation: one that looks to the intent of the author, and one that acknowledges the free play of the text. Derrida's critique, however, extends much further. As soon as the author's original intent is displaced as the foundation of interpretative practice, the critic finds that she must substitute a new ground for her interpretative theory, and this theory too, must depend upon and define itself in terms of that which it excludes. Thus, the critic who replaces 'original intent' by 'intersubjective meaning,' 'historical development,' or 'shared consensus of values,' must reinstitute a new form of presence, which is subject to further deconstruction. ${ }^{113}$

*786 III. CONCLUSION

113 Consider, for example, theorists who advocate using tradition, moral consensus, or conventional morality as the basis of constitutional interpretation. See, e.g., Lupu, Untangling the Strands of the Fourteenth Amendment, $77 \mathrm{MICH}$. L. REV. 981, 985, 1040-41 (1979); Perry, Substantive Due Process Revisited: Reflections on (and Beyond) Recent Cases, 71 NW. U.L. REV. 417, 425 (1976); Wellington, Common Law Rules and Constitutional Double Standards: Some Notes on Adjudication, 83 YALE L.J. 221, 284 (1973). Such a proposal involves a privileging of traditional over nontraditional values, of non-controversial over controversial attitudes, and of conventional over nonconventional morality. Dean Ely deconstructs this privileging by showing that arguments for this interpretative theory undo themselves: '[P]art of the point of the Constitution is to check today's majority . ... 'If the Constitution protects only interests which comport with traditional values, the persons most likely to be penalized for their way of life will be those least likely to receive judicial protection." J. ELY, DEMOCRACY AND DISTRUST 62 (1980) (quoting Karst, The Supreme Court, 1976 Term Foreword: Equal Citizenship Under the Fourteenth Amendment, 91 HARV. L. REV. 70, 136 (1977)). Thus, the argument for enforcing the privileged concept, traditional values, becomes an argument for enforcing the excluded concept, non-traditional values. Similarly, one can show that the argument for enforcing values agreed upon by a majority of the public deconstructs itself. As Ely notes, 'it makes no sense to employ the value judgments of the majority as the vehicle for protecting minorities from the value judgments of the majority.' Id. at 69 . 
Deconstruction by its very nature is an analytic tool and not a synthetic one. It can displace a hierarchy momentarily, it can shed light on otherwise hidden dependences of concepts, but it cannot propose new hierarchies of thought or substitute new foundations. These are by definition logocentric projects, which deconstruction defines itself against. Deconstruction is thus revelatory, and what the legal theorist does with the revelation is not dictated by the deconstruction itself, nor could it be.

In theory then, deconstructive readings of legal texts can be a tool of analysis for the right as well as for the left. In practice, left legal scholars will probably make more use of deconstructive techniques for two reasons: first, because of the historical connection between continental philosophy and left political thought, and second, because the left usually has more to gain from showing the ideological character of the status quo than does the right. ${ }^{114}$

Deconstructive readings, at least in the sense used in this Article, do not demonstrate that legal thought is incoherent any more than they demonstrate that all forms of logocentric practice are incoherent. Similarly, deconstructive readings do not demonstrate that legal thought is any more irrational than any other form of logocentric thought. Rather, what deconstruction demonstrates is the differance between what is privileged and what is excluded in legal thought. Deconstruction thus reveals the antinomal character of legal thought, a characterization which is at first disturbing, but in the end is the best descriptionof our actual experience in using legal concepts.

114 On the other hand, an economic libertarian might well use deconstructive techniques to criticize the modern welfare state on the grounds that it rests upon a false privileging of certain aspects of human nature. 